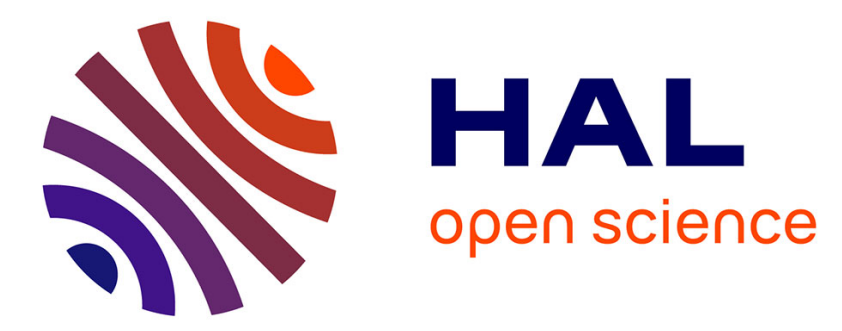

\title{
Tetra-CMPO-Derivatives of Calix[4]arenes fixed in the 1,3-Alternate Conformation
}

Crenguta Dordea, Frédéric Brisach, Jaouad Haddaoui, Françoise Arnaud-Neu, Michael Bolte, Alessandro Casnati, Volker Böhmer

\section{To cite this version:}

Crenguta Dordea, Frédéric Brisach, Jaouad Haddaoui, Françoise Arnaud-Neu, Michael Bolte, et al.. Tetra-CMPO-Derivatives of Calix[4]arenes fixed in the 1,3-Alternate Conformation. Supramolecular Chemistry, 2010, 22 (06), pp.347-357. 10.1080/10610271003678511 . hal-00590752

\section{HAL Id: hal-00590752 https://hal.science/hal-00590752}

Submitted on 5 May 2011

HAL is a multi-disciplinary open access archive for the deposit and dissemination of scientific research documents, whether they are published or not. The documents may come from teaching and research institutions in France or abroad, or from public or private research centers.
L'archive ouverte pluridisciplinaire HAL, est destinée au dépôt et à la diffusion de documents scientifiques de niveau recherche, publiés ou non, émanant des établissements d'enseignement et de recherche français ou étrangers, des laboratoires publics ou privés. 


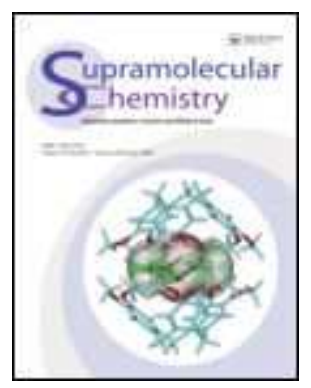

\section{Tetra-CMPO-Derivatives of Calix[4]arenes fixed in the 1,3- Alternate Conformation}

\begin{tabular}{|r|l|}
\hline Journal: & Supramolecular Chemistry \\
\hline Manuscript ID: & GSCH-2009-0127.R1 \\
\hline Manuscript Type: & Full Paper \\
\hline Date Submitted by the & 08-Jan-2010 \\
\hline Complete List of Authors: & $\begin{array}{l}\text { Dordea, Crenguta; Johannes Gutenberg-Universität Mainz, } \\
\text { Fachbereich Chemie, Pharmazie und Geowissenschaften } \\
\text { Brisach, Frédéric; IPHC-DSA, UDS, CNRS, ECPM } \\
\text { Haddaoui, Jaouad; IPHC-DSA, UDS, CNRS, ECPM } \\
\text { Arnaud-Neu, Françoise; IPHC-DSA, UDS, CNRS, ECPM } \\
\text { Bolte, Michael; Johann Wolfgang Goethe-Universität Frankfurt, } \\
\text { Fachbereich Chemie und Pharmazeutische Wissenschaften, Institut } \\
\text { für Anorganische Chemie } \\
\text { Casnati, Alessandro; Dipartimento di Chimica Organica e Industriale } \\
\text { dell'Università } \\
\text { Böhmer, Volker; Johannes Gutenberg-Universität Mainz, } \\
\text { Fachbereich Chemie, Pharmazie und Geowissenschaften }\end{array}$ \\
\hline Keywords: & $\begin{array}{l}\text { Lanthanides, calix[4]arenes, complexation, extraction, crystal } \\
\text { structures }\end{array}$ \\
\hline
\end{tabular}

\section{今 ScholarONE \\ Manuscript Central}




1
2
3
4
5
6
7
8
9
10
11
12
13
14
15
16
17
18
19
20
21
22
23
24
25
26
27
28
29
30
31
32
33
34
35
36
37
38
39
40
41
42
43
44
45
46
47
48
49
50
51
52
53
54
55
56
57
58
60

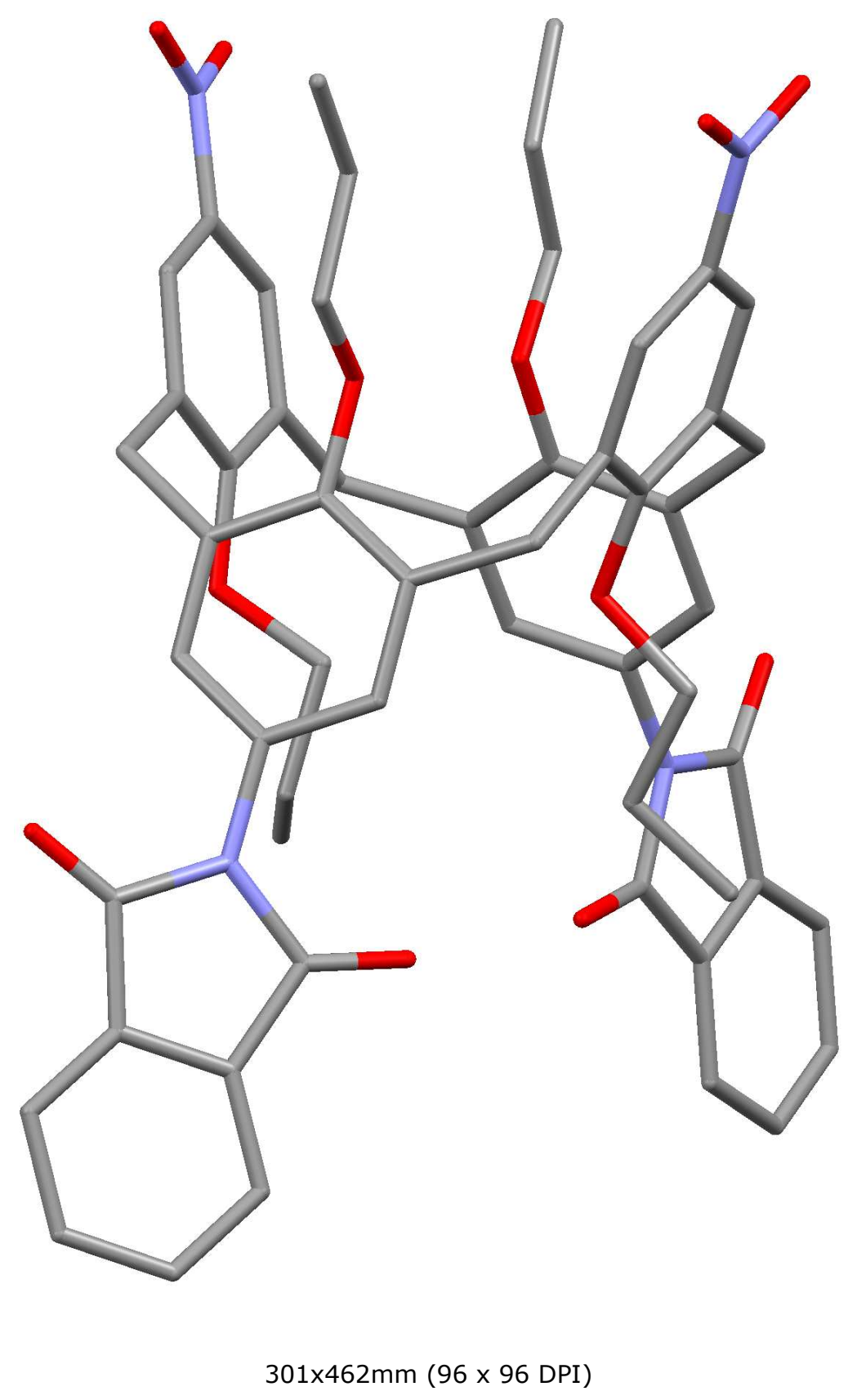

URL: http:/mc.manuscriptcentral.com/tandf/gsch Email: suprachem@mail.cm.utexas.edu 


\title{
Tetra-CMPO-Derivatives of Calix[4]arenes fixed in the 1,3-Alternate Conformation
}

\author{
Crenguta Dordea, ${ }^{a}$ Frédéric Brisach, ${ }^{b}$ Jaouad Haddaoui, ${ }^{b}$ Françoise Arnaud-Neu, ${ }^{b}$ Michael Bolte, ${ }^{c}$ \\ Alessandro Casnatid and Volker Böhmer ${ }^{* a}$ \\ ${ }^{a}$ Fachbereich Chemie, Pharmazie und Geowissenschaften, Johannes Gutenberg-Universität, Mainz, Germany. \\ ${ }^{b}$ IPHC-DSA, UDS, CNRS, ECPM, Strasbourg, France. \\ ${ }^{c}$ Fachbereich Chemie und Pharmazeutische Wissenschaften, Institut für Anorganische Chemie, Johann \\ Wolfgang Goethe-Universität Frankfurt, Germany. \\ ${ }^{d}$ Dipartimento di Chimica Organica e Industriale dell'Università, Parma, Italy \\ *Corresponding author.E-mail:vboehmer@uni-mainz.de
}

\begin{abstract}
.
Calix[4]arene derivatives fixed in the 1,3-alternate conformation and substituted at one side by four carbamoylmethylphosphine oxide residues (=CMPO) were synthesized. Two CMPO groups are directly attached to the wide rim while the second pair is bound to the narrow rim via a tri- or tetramethylene spacer. Similar compounds, in which two CMPO groups at the wide rim are combined with two picolinamide groups or two 20 ionisable carboxylic groups at the narrow rim were also prepared. Some of these calixarene derivatives were studied as extractants for lanthanides $\left(\mathrm{La}^{3+}, \mathrm{Eu}^{3+}, \mathrm{Yb}^{3+}\right)$ and thorium $\left(\mathrm{Th}^{4+}\right)$ from acidic solution to methylenechloride. For selected samples stability constants in methanol were determined by spectrophotometric titrations. Three compounds $(\mathbf{1 b}, \mathbf{1 3}, \mathbf{1 7})$ in the 1,3 -alternate conformation and one intermediate in the cone conformation (18) were confirmed by a crystal structure.
\end{abstract}

\section{${ }_{25}$ Keywords:}

Lanthanides, calix[4]arenes, complexation, extraction, crystal structures.

\section{Introduction}

${ }_{30}$ Carbamoylmethylphosphine oxides (CMPOs) are efficient extractants for actinides (and lanthanides) and especially the N,N-diisobutyl derivative is used on a technical scale (TRUEX-process). ${ }^{1}$ CMPO is a bidentate ligand, and a trivalent cation surely binds more than one molecule of the ligand in its complex. Thus it appeared reasonable to attach several CMPO functions to a common platform. In fact tri-CMPO derivatives of triphenylmethanes ${ }^{2}$ and tetraCMPO derivatives of calix[4]arenes ${ }^{3}$ are much more efficient extractants than CMPO itself. This is true for ${ }_{35}$ compounds, where the CMPO functions are attached to the wide rim $^{4}$ or to the narrow rim ${ }^{5}$ Better extraction results are even obtained with linear ${ }^{6}$ oligo-CMPOs and with calix[4]arenes bearing only two or three CMPO functions. ${ }^{7}$

Calix [4]arenes bearing ether residues equal to or larger than propyl are fixed in one of the four basic conformations (cone, partial cone, 1,2- and 1,3-alternate). Nearly all calix[4]arene derived ligands of the podand-type are based on the cone conformation ${ }^{8}$ where all oxygens (and all $p$-positions) point in the same direction, although rare examples 40 with other conformations are known ${ }^{9,10,11}$ It should be possible, however, to use also the 1,3-alternate conformation as scaffold ${ }^{12}$, if the ligating groups are attached alternatingly to the wide and to the narrow rim, where an appropriate spacer could bring them to the same level. The 1,3-alternate skeleton is more rigid compared to the cone isomers, which still can change between two „pinched" cone conformations. Considering the fact that a tetra-CMPO derived from a rigid biscrown-3 calix[4]arene is by a factor of 10 more efficient as extractant, ${ }^{13}$ this rigidity could be even ${ }_{45}$ advantageous.

It should be also worthwhile to attach different ligating functions to the wide and narrow rim of the calix[4]arene in its 1,3-alternate conformation. Picolinamide groups, for instance, should lead to a better selectivity than CMPO functions alone. ${ }^{14,15,16}$ Carboxylic acids could potentially act as anion exchanger and reduce the number of nitrate anions to be extracted into the organic phase. Lipophilic carboxylic acids are often used as synergisers for neutral ${ }_{50}$ ligands in nuclear waste treatment, ${ }^{17}$ while polycarboxylic acids were proven to efficiently complex actinide ${ }^{18}$ and lanthanide ${ }^{19}$ cations. $^{20}$ 


\section{Results and discussion}

Syntheses. Aminogroups attached to the wide rim of a calix[4]arene are usually obtained by reduction of nitrogroups which are often introduced via ipso-nitration. ${ }^{21}$ For the attachment at the narrow rim the alkylation by $\mathrm{N}-(\omega-$ bromoalkyl)phthalimides (or by $\omega$-bromoalkylnitriles) followed by hydrazinolysis of the phthalimide groups (or by ${ }_{5}$ reduction of the nitrile groups) are convenient methods.

Since selective substitutions are possible only at the wide rim distinguishing phenol and phenolether units ${ }^{22}$ the following two pathways (Scheme 1) were checked, starting with the known 1,3-alternate derivative $\mathbf{1}^{23}$

a): Catalytic hydrogenation leads in excellent yields to the propoxy aniline derivative (amino propyl ether) 2a,b $(n=3,4)$ which was acylated by the active ester $\mathbf{A E} 1^{3,24}$ to give $\mathbf{3 b}$ in $84 \%$. (For $n=2$ the product could not be ${ }_{10}$ sufficiently purified, for $n=4$ this pathway was not further followed.) Cleavage of the phthalimide by hydrazine (93\% of $\mathbf{4 b}$ ) and acylation of the aliphatic amino groups by AE1 (83\% of $\mathbf{5 b}(n=3))$ occurred without problems.

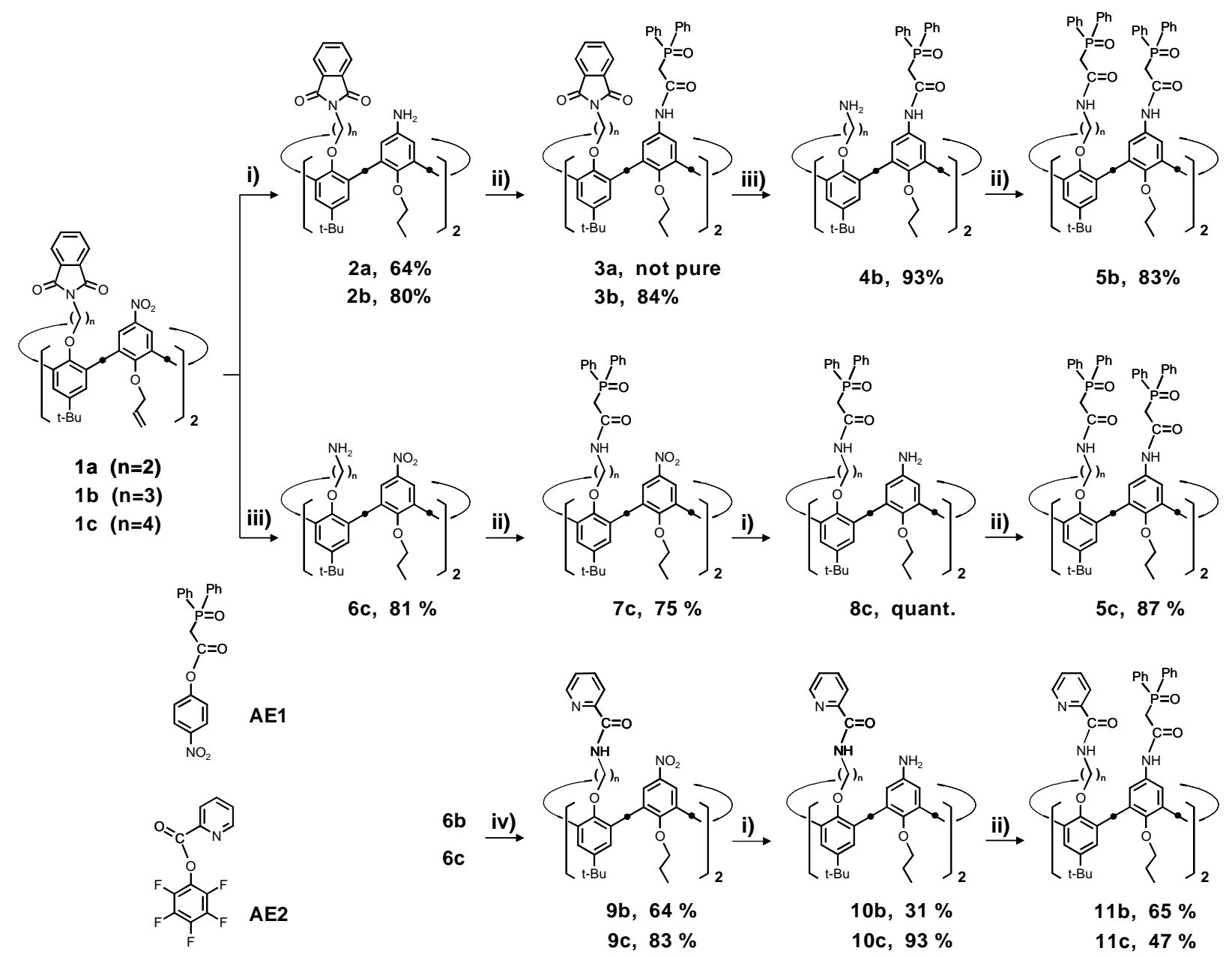

Scheme 1 Syntheses of tetra-CMPO derivatives of calix[4]arenes in the 1,3-alternate conformation and of compounds bearing two CMPO and two picolinamide residues. i) $\mathrm{H}_{2}$, Raney-Ni, THF, rt; ii) $\mathbf{A E 1}, \mathrm{CH}_{2} \mathrm{Cl}_{2}$, rt; iii) hydrazine, EtOH, reflux; iv) $\mathbf{A E 2}, \mathrm{CH}_{2} \mathrm{Cl}_{2}, \mathrm{rt}$. 


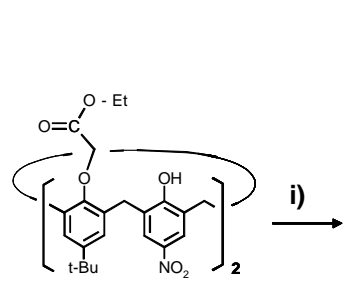

12

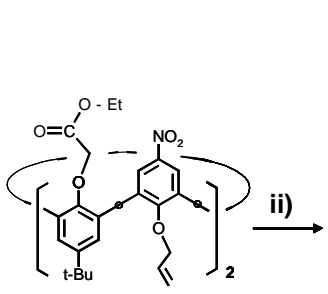

13, $21 \%$

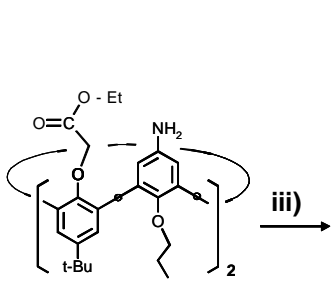

14

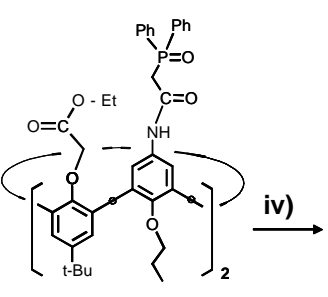

15, $92 \%$

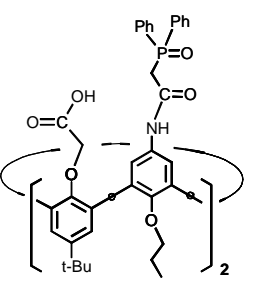

$16,96 \%$

Scheme 2 Synthesis of 1,3-alternate derivatives combining two $\mathrm{CMPO}$ with two carboxylic groups. i) allylbromide, $\mathrm{Cs}_{2} \mathrm{CO}_{3}, \mathrm{DMF}, 50{ }^{\circ} \mathrm{C}$; ii) $\mathrm{H}_{2}, \mathrm{Raney}-$ Ni, THF, rt; iii) AE1, $\mathrm{CH}_{2} \mathrm{Cl}_{2}$, rt; iv) $\mathrm{LiOH}, \mathrm{THF} / \mathrm{MeOH}$, rt.

b): Alternatively (as studied for $n=4$ ), cleavage of the phthalimide groups (of 1c) with hydrazine occurred with the ${ }_{5}$ simultaneous hydrogenation of the allyl groups to give $81 \%$ of 6c. Subsequent acylation by AE1 (75\% of 7c) followed by quantitative hydrogenation of the nitro groups to 8c and a second acylation step by AE1 (87\% of 5c $(n=4)$ ) was also possible without any problems. It should be mentioned that the allyl groups must not be quantitatively hydrogenated during the cleavage of the phthalimide groups, since this will be completed in the next step. It is important, however, that the cleavage of the phthalimide groups is quantitative while nitro groups remain 10 unchanged.

A direct conversion of $\mathbf{1}$ to the respective tetra amine (simultaneous or subsequent cleavage of the phthalimide groups and reduction of the nitro groups) was not attempted, although it should be more economic for those cases, where only one acyl-residue has to be attached.

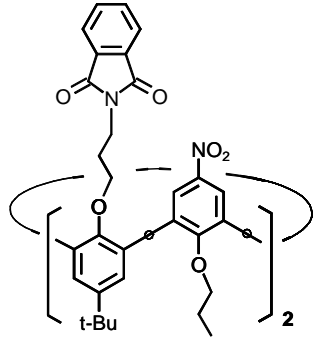

$1 b^{\prime}$

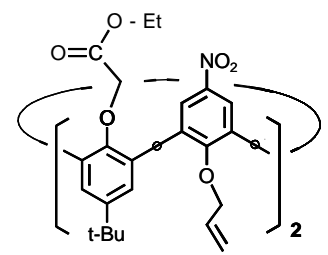

13
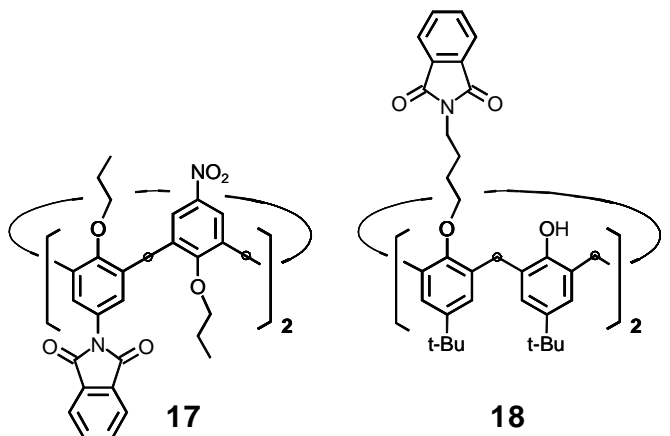

Table 1 Extraction of selected lanthanides and thorium by tetra-CMPOs $\mathbf{5}, \mathrm{c}_{\mathrm{L}}=10^{-3} \mathrm{M}\left(\mathrm{c}_{\mathrm{L}}=10^{-4} \mathrm{M}\right)$; values for a narrow and a wide rim tetra-CMPO fixed in the cone conformation are included for comparison.

\begin{tabular}{|c|c|c|c|c|c|}
\hline & & $\mathrm{La}^{3+}$ & $\mathrm{Eu}^{3+}$ & $\mathrm{Yb}^{3+}$ & $\mathrm{Th}^{4+}$ \\
\hline \multirow[t]{2}{*}{$5 b$} & $\% \mathrm{E}$ & 11 & 11 & 9 & (17) \\
\hline & $\mathrm{D}$ & 0.12 & 0.12 & 0.09 & $(0.2)$ \\
\hline \multirow[t]{2}{*}{$5 c$} & $\% \mathrm{E}$ & 12 & 10 & 11 & $48(12)^{a}$ \\
\hline & D & 0.13 & 0.11 & 0.12 & $0.92(0.13)^{a}$ \\
\hline narrow rim ${ }^{5}$ & $\% \mathrm{E}$ & 70 & 68 & 37 & (96) \\
\hline$(\mathrm{n}=3)$ & $\mathrm{D}$ & 2.33 & 2.12 & 0.58 & (24) \\
\hline \multirow[t]{2}{*}{${\text { wide } \text { rim }^{6,7}}^{6}$} & $\% \mathrm{E}$ & 98 & 64 & 6.6 & (61.8) \\
\hline & $\mathrm{D}$ & 49 & 1.78 & 0.07 & (1.62) \\
\hline
\end{tabular}

${ }^{a}$ Values for $\mathrm{c}_{\mathrm{L}}=10^{-4} \mathrm{M}$.

20 Table 2 Stability constants $\left(\log \beta \pm \sigma_{\mathrm{n}-1}\right)$ for complexes of tetra-CMPOs 5 with some lanthanides in methanol at $25^{\circ} \mathrm{C}(\mathrm{I}=$ $10^{-2} \mathrm{M}, \mathrm{Et}_{4} \mathrm{NNO}_{3}$ ). Data for a wide rim tetra-CMPO in the cone conformation are included for comparison.

$\begin{array}{ccccc} & & \mathrm{La}^{3+} & \mathrm{Eu}^{3+} & \mathrm{Yb}^{3+} \\ \mathbf{5 b} & 1: 1 & 5.5 \pm 0.2 & 4.7 \pm 0.2 & 5.1 \pm 0.2 \\ \mathbf{5 c} & 1: 1 & 4.2 \pm 0.2 & 3.9 \pm 0.2 & 3.2 \pm 0.2 \\ \text { wide } \mathbf{r i m}^{26} & 1: 1 & 6.0 & 5.6 & 3.5 \\ & 2: 1 & 10.6 & 11.0 & 8.6\end{array}$

Two similar calixarene derivatives combining two picolinamide functions ${ }^{25}$ at the narrow rim (attached via three or four methylene groups) with two CMPO functions at the wide rim, were prepared in analogy to pathway $\boldsymbol{b}$ ). Acylation of $\mathbf{6 b}, \mathbf{c}$ with AE2, the hexafluorophenyl ester of $\alpha$-picolinic $\operatorname{acid}^{27}(64 \% / 83 \%$ of $\mathbf{9 b}, \mathbf{c})$, reduction of the nitro groups 
(31\%/93\% of 10b,c) and acylation with AE1 (65\%/47\% of 11b,c). The partly striking difference in the yield for the last steps indicates that the reaction conditions are not optimized. These syntheses of extractants $\mathbf{5}$ and $\mathbf{1 1}$ are summarized in Scheme 1.

In order to (partly) compensate the positive charge of the extracted cation we prepared compound 16, where two ${ }_{5}$ CMPO functions are combined with two carboxyl groups. The synthesis starts with the known ${ }^{28}$ diester 12 which is fixed in the 1,3-alternate conformation as di-allylether $\mathbf{1 3}$ (isolated yield 21\%, together with $39 \%$ of the isomer in the partial cone conformation). Reduction/hydrogenation and direct acylation of the crude diamine $\mathbf{1 4}$ furnished the diester 15 (92\%) which was hydrolysed by aqueous LiOH to give the di-CMPO-di-acid $\mathbf{1 6}$ with $96 \%$ yield. (see Scheme 2).

${ }_{10}$ Extraction and Complexation. The extraction of selected cations (lanthanides and thorium) from $1.0 \mathrm{M}$ nitric acid into dichloromethane was studied for two tetra-CMPO compounds $(\mathbf{5 b}, \mathbf{5 c})$. The respective extraction percentages $\% \mathrm{E}$ and distribution coefficients D are given in Table 1 and compared with values previously obtained ${ }^{5-7}$ for calixarenes fixed in the cone conformation and substituted at the wide or narrow rim by four CMPO-functions. These data show that the extraction ability of lanthanides is similar for $\mathbf{5 b}$ and $\mathbf{5 c}$ (and practically identical for $\mathrm{La}^{3+}, \mathrm{Eu}^{3+}, \mathrm{Yb}^{3+}$ ), but 15 five to twenty times lower than for the analogues in the cone conformation. The stability constants of the complexes, however, are distinctly higher (by factors of 6 to 80 ) for $\mathbf{5 b}$ than for $\mathbf{5} \mathbf{c}$ (Table 2).

By all criteria, however, wide as well as narrow rim tetra-CMPOs in the cone conformation are better extractants/ligands than the derivatives in the 1,3-alternate conformation, which in addition are more difficult to synthesize. Both data sets show no real selectivity within the lanthanide series in contrast with the lower and 20 especially the upper rim derivatives.

Crystal structures. Single crystals suitable for X-ray diffraction were obtained for three compounds fixed in the 1,3alternate conformation, 1b' (obtained from $\mathbf{1 b}$ by selective hydrogenation of the allyl groups, or by direct alkylation, using propyl- instead of allylbromide), 13, and $\mathbf{1 7}$ (a derivative with two different precursor functions for amino groups at the wide rim $^{23}$ ). A crystal structure was also determined for the 1,3-diether $\mathbf{1 8}$ in the cone conformation, ${ }^{29}$ ${ }_{25}$ the very first step in the synthesis of $\mathbf{1 c}$.

18 assumes the usual pinched cone conformation where the aryl residues of the phenolic units are bent outwards, including angles of $148.7^{\circ}$ and $132.2^{\circ}$ with the reference plane defined by the four methylene bridge carbons. Consequently the two ether aryl units are bent towards the cavity, with angles of $114.7^{\circ}$ and $108.9^{\circ}$. This conformation (with interplanar angles between opposite calix[4]arene aryl planes of $100.9^{\circ}$ and $43.6^{\circ}$ ) permits a 30 slightly larger distance between the (bulky) ether residues (distances O12-O32 = 4.534 $\AA$ and O22-O42 = 3.222 ). The orientation of the phthalimide planes is obviously mainly determined by packing requirements, since the $\left(\mathrm{CH}_{2}\right)_{4}{ }^{-}$ linker (tetramethylene linker) allows for conformational freedom.

Table 3 Comparison of some typical data taken from the crystal structures of three different calix[4]arene derivatives in the 1,3-alternate conformation $(\mathbf{1 b}, \mathbf{1 3}, \mathbf{1 7})$ and one in the cone conformation $(\mathbf{1 8})$

\begin{tabular}{|c|c|c|c|c|c|}
\hline Compounds: & & 1b' & $\mathbf{1 3} \cdot \mathrm{CHCl}_{3}$ & 17 & $182 \mathrm{H}_{2} \mathrm{O}$ \\
\hline \multicolumn{6}{|l|}{ Distances (@) } \\
\hline within the & $\mathrm{C} 1-\mathrm{C} 2$ & 5.139 & 5.108 & 5.145 & 5.120 \\
\hline \multirow[t]{5}{*}{ reference plane } & $\mathrm{C} 2-\mathrm{C} 3$ & 5.110 & 5.137 & 5.134 & 5.105 \\
\hline & $\mathrm{C} 3-\mathrm{C} 4$ & 5.185 & 5.130 & 5.109 & 5.129 \\
\hline & $\mathrm{C} 4-\mathrm{C} 1$ & 5.144 & 5.125 & 5.123 & 5.105 \\
\hline & $\mathrm{C} 1-\mathrm{C} 3$ & 7.266 & 7.061 & 6.944 & 7.291 \\
\hline & $\mathrm{C} 2-\mathrm{C} 4$ & 7.278 & 7.365 & 7.412 & 7.173 \\
\hline phenolic oxygens & $\mathrm{O} 22-\mathrm{O} 42$ & 4.149 & 4.585 & 4.546 & 3.222 \\
\hline \multirow[t]{2}{*}{ opposite $p-\mathrm{C}$ atoms } & $\mathrm{C} 15-\mathrm{C} 35$ & 7.989 & 7.481 & 7.487 & 7.466 \\
\hline & $\mathrm{C} 25-\mathrm{C} 45$ & 7.377 & 6.326 & 6.580 & 9.548 \\
\hline \multicolumn{6}{|l|}{ Angles $\left(^{\circ}\right)$} \\
\hline \multirow[t]{4}{*}{ with main plane } & $p-t \mathrm{Bu}$ & 112.3 & 113.1 & $120.6^{a}$ & 148.7 \\
\hline & & 131.9 & 109.5 & $104.5^{a}$ & 132.2 \\
\hline & $p-\mathrm{NO}_{2}$ & 112.0 & 107.4 & 111.2 & 114.7 \\
\hline & & 115.4 & 99.9 & 100.7 & 108.9 \\
\hline planes & $p-\mathrm{NO}_{2}$ & 47.4 & 27.4 & 31.9 & 100.9 \\
\hline \multicolumn{6}{|l|}{ within main plane } \\
\hline \multicolumn{2}{|l|}{ folding $\mathrm{C} 1-\mathrm{C} 3$} & 4.8 & 15.0 & 21.7 & 2.5 \\
\hline \multicolumn{2}{|l|}{ folding C2-C4 } & 4.8 & 15.6 & 23.1 & 2.5 \\
\hline
\end{tabular}



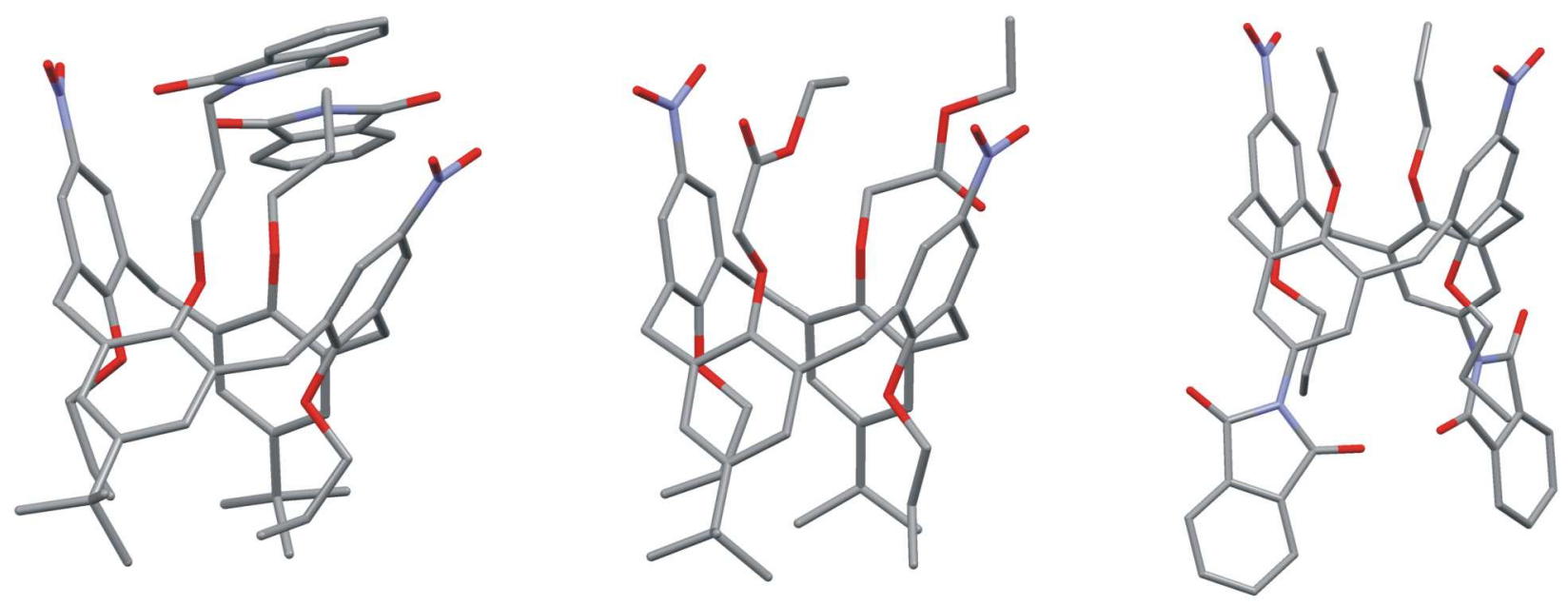

Fig. 1 Molecular conformation of the three 1,3-alternate derivatives $\mathbf{1 b}$ ', 13, and $\mathbf{1 7}$ (from the left to the right) 
1

2

3

4

5

6

7

8

9

10

11

12

13

14

15

16

17

18

19

20

21

22

23

24

25

26

27

28

29

30

31

32

33

34

35

36

37

38

39

40

41

42

43

44

45

46

47

48

49
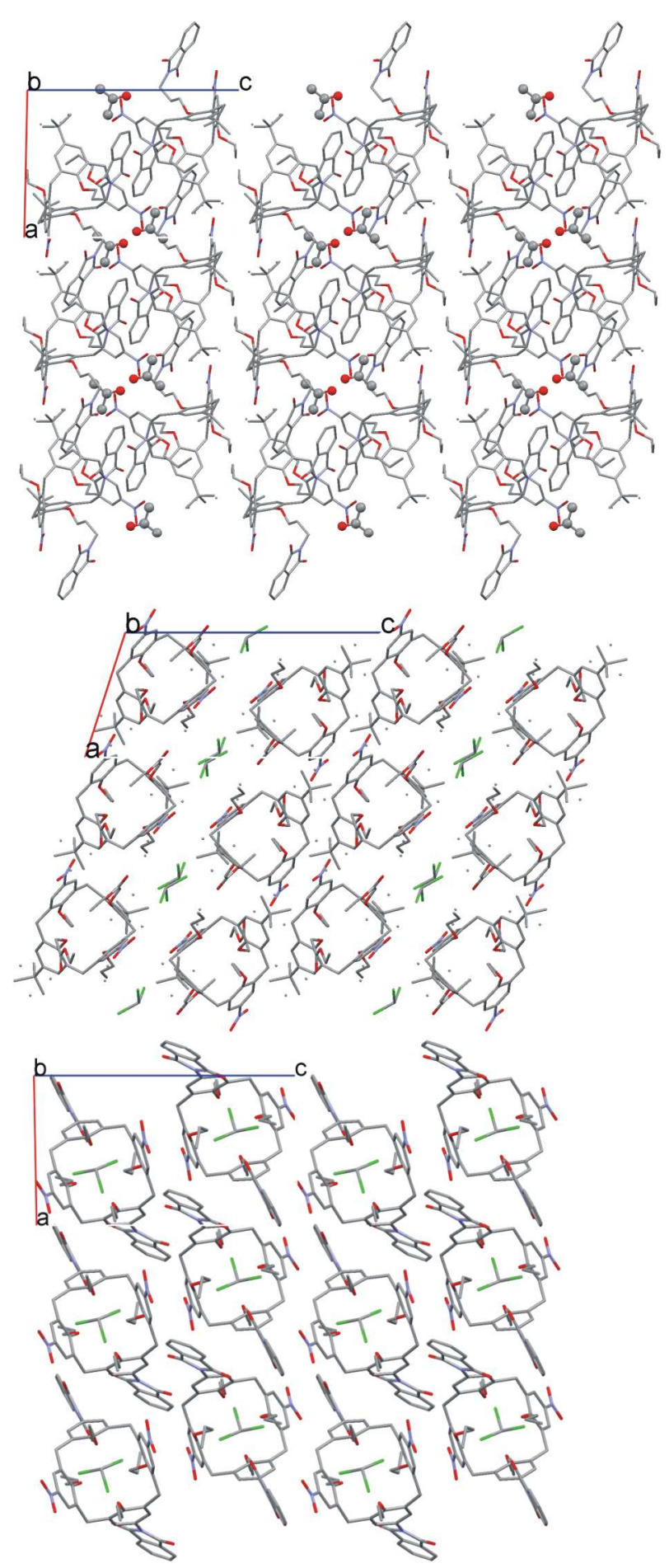

Fig. 2 Packing of molecules seen along the b-axis in the lattice of $\mathbf{1 b}$ ', $\mathbf{1 3}$ and $\mathbf{1 7}$ (from the top to the botom); for $\mathbf{1 b}$ 'the included acetone molecules are shown as "ball and stick" models. .

The best plane through the $\mathrm{C}$-atoms of the bridging methylene groups is a suitable reference plane also for the s derivatives in the 1,3-alternate conformation, although the deviation from this common plane reaches $0.357 \AA$ for $\mathbf{1 7}$, with the four carbon atoms laying alternatingly on both sides (for $\mathbf{1 3}$ and $\mathbf{1 b}$ ' this deviation is 0.243 and $0.076 \AA$ ). The shape of the molecule may be characterised then by the angle between the aromatic planes and this reference plane (see Table 3). The deviation of the reference plane from an geometrically exact plane can be characterised also by the angle between two triangles obtained by folding along the diagonal (C1-C3 or $\mathrm{C} 2-\mathrm{C} 4)$. These angles are small ${ }_{10}\left(4.75^{\circ}\right)$ for $\mathbf{1} \mathbf{b}^{\prime}$, but larger for $\mathbf{1 3}\left(15.00 / 15.64^{\circ}\right)$ and $\mathbf{1 7}\left(21.70 / 23,12^{\circ}\right)$.

However, this folding does not entirely explain the strong differences found for the distances of opposite phenolic 
oxygens (largest for 1b', $\Delta=0.561 \AA$ ) and opposite p-aryl carbons (largest for 13, $\Delta=1.155 \AA$ ). Most probably also packing effects are responsible for such deviations in the exact shape of the 1,3-alternate skeleton, since especially the $p$-substitients ( $t$-butyl, nitro, phthalimido) are rather different in size, shape and polarity.

Further distances and angles of the three molecules with 1,3-alternate conformation are compared in Table 3, which contains also data for two compounds (precursors) in the cone conformation. The molecular conformation of compounds 1b', 13 and $\mathbf{1 7}$ is compared in Fig. 1, while their packing is compared in Fig. 2.

In the crystal lattice $\mathbf{1 3} \cdot \mathrm{CHCl}_{3}$ forms columns with alternating directionality parallel to the b-axis. Within the a-bplane these columns form double layers separated by channels which contain the chloroform molecules (Fig. 2, middle). 17. $\mathrm{CHCl}_{3}$ forms similar columns along the b-axis, but here the molecules within each column are separated 10 by solvent molecules, which are "included" in the cavity surrounded by the phthalimide and the nitro groups. The larger size of this cavity, compared with 13, may be the reason for this inclusion. Otherwise both structures are rather similar. A description of the packing of $\mathbf{1 b}$ ' is more complicated. Fig. 2 (left) shows a view along the b-axis in which the included acetone molecules are shown in "ball and stick" representation.

\section{Experimental Part}

${ }_{15}$ Syntheses. Compounds 1b, 1c, 2 b and $\mathbf{6 b}$ were prepared as described earlier.Error! Bookmark not defined.

5,17-Di-t-butyl-11,23-dinitro-26,28-diphthalimidoethyloxy-25,27-di-allyloxy-calix[4]arene 1a. Compound 1a was obtained (together with its partial cone isomer) as described for the analogous compounds 1b and 1c from the dinitro compound. A suspension of 5,17-Di-t-butyl-11,23-dinitro-26,28-diphthalimidoethyloxy-calix[4]arene (2.9 g, $2.98 \mathrm{mmol})$ in dry DMF $(40 \mathrm{ml})$ and $\mathrm{Cs}_{2} \mathrm{CO}_{3}(7.8 \mathrm{~g}, 23 \mathrm{mmol})$ was stirred under nitrogen at $50{ }^{\circ} \mathrm{C}$ for 6 days. Water $20(50 \mathrm{ml})$ was added to stop the reaction and after several washing $(3 \times 50 \mathrm{ml}$ water $)$ the organic phase was dried over $\mathrm{MgSO}_{4}$. The solvent was evaporated under reduced pressure. Colourless crystals $(0.05 \mathrm{~g}, 2 \%)$ of the desired $1,3-$ alternate isomer 1a were isolated by column chromatography (chloroform/hexane, 1:2) together with the partial cone isomer $(0.27 \mathrm{~g}, 9 \%)$. Clearly these yields are not optimized.

1a: m.p. $251-253{ }^{\circ} \mathrm{C}$; ${ }^{1} \mathrm{H}$ NMR $\left(300 \mathrm{MHz} \mathrm{CDCl}_{3}\right) \delta 1.78\left(\mathrm{~s}, 18 \mathrm{H}, t\right.$-Bu), 3.72, $3.86\left(2 \mathrm{~d}, 4 / 4 \mathrm{H},{ }^{2} J=15.6 \mathrm{~Hz}, \mathrm{Ar}-\right.$ $\left.{ }_{25} \mathrm{CH}_{2}-\mathrm{Ar}\right), 3.79\left(\mathrm{~m}, 8 \mathrm{H}, \mathrm{O}-\mathrm{CH}_{2}-,-\mathrm{CH}_{2}-\mathrm{N}\right), 4.10\left(\mathrm{~d}, 4 \mathrm{H},{ }^{2} \mathrm{~J}=5.16 \mathrm{~Hz}, \mathrm{CH}_{2}=\mathrm{CH}-\mathrm{CH}_{2}-\mathrm{O}-\right), 5.08(\mathrm{~m}, 4 \mathrm{H}, \mathrm{CH}=\mathrm{CH}-), 5.75$ $\left(\mathrm{m}, 2 \mathrm{H}, \mathrm{CH}_{2}=\mathrm{CH}-\right), 6.95,8.28(2 \mathrm{~s}, 4 / 4 \mathrm{H}, \mathrm{Ar} H), 7.66-7.85(\mathrm{~m}, 8 \mathrm{H}, \mathrm{Phth}-\mathrm{H})$.

partial cone isomer of 1a: m.p. $215-217{ }^{\circ} \mathrm{C} ;{ }^{1} \mathrm{H}$ NMR $\left(300 \mathrm{MHz}, \mathrm{CDCl}_{3}\right) \delta 1.00(\mathrm{~s}, 18 \mathrm{H}, t-\mathrm{Bu}), 3.24\left(\mathrm{~d}, 2 \mathrm{H},{ }^{2} J=\right.$ $\left.13.2 \mathrm{~Hz}, \mathrm{Ar}-\mathrm{CH}_{2}-\mathrm{Ar}\right), 3.70-4.25\left(\mathrm{~m}, 18 \mathrm{H}, \mathrm{O}-\mathrm{CH}_{2-},-\mathrm{CH}_{2}-\mathrm{N}, \mathrm{Ar}-\mathrm{CH}_{2}-\mathrm{Ar},-\mathrm{O}-\mathrm{CH}_{2}-\mathrm{CH}=\mathrm{CH}_{2}\right), 4.85,5.22(2 \mathrm{~m}, 2 / 2 \mathrm{H}$, $\left.\mathrm{CH}_{2}=\mathrm{CH}-\right), 5.56,5.88\left(2 \mathrm{~m}, 1 / 1 \mathrm{H}, \mathrm{CH}_{2}=\mathrm{CH}-\right), 6.57,6.88\left(2 \mathrm{~d}, 2 / 2 \mathrm{H},{ }^{4} \mathrm{~J}=2.2 \mathrm{~Hz}, \mathrm{Ar} H\right), 7.82(\mathrm{~m}, 8 \mathrm{H}, \mathrm{Phth}-\mathrm{H}), 8.00$, $308.42(2 \mathrm{~s}, 2 / 2 \mathrm{H}, \mathrm{ArH})$.

5,17-Di-t-butyl-11,23-diamino-26,28-diphthalimidoethoxy-25,27-dipropoxy-calix[4]arene 2a. The diamine 2a

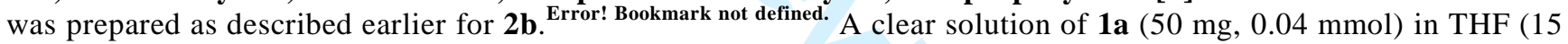
$\mathrm{ml}$ ) was hydrogenated under normal pressure with Raney-Ni. The catalyst was filtered off, the solvent was evaporated and the dry residue was dissolved in $\mathrm{CHCl}_{3}(3 \mathrm{ml})$ and reprecipitated with hexane to give $2 \mathbf{a}$ as yellow powder $(30$ $35 \mathrm{mg}, 64 \%)$; mp $315^{\circ} \mathrm{C} ;{ }^{1} \mathrm{H}$ NMR $\left(300 \mathrm{MHz}, \mathrm{CDCl}_{3}\right) \delta 0.57\left(\mathrm{t}, 6 \mathrm{H},{ }^{3} \mathrm{~J}=7.16 \mathrm{~Hz}, \mathrm{CH}_{3}-\mathrm{CH}_{2^{-}}\right), 1.23(\mathrm{~s}, 18 \mathrm{H}, t-\mathrm{Bu}), 3.17$ (bt, $\left.4 \mathrm{H},-\mathrm{NH}_{2}\right), 3.45-3.60\left(2 \mathrm{bt}, 4 / 4 \mathrm{H},-\mathrm{CH}_{2}-\mathrm{N}, \mathrm{O}-\mathrm{CH}_{2}-\right), 3.74,3.84\left(2 \mathrm{~d}, 4 / 4 \mathrm{H},{ }^{2} \mathrm{~J}=12.2 \mathrm{~Hz}, \mathrm{Ar}-\mathrm{CH}_{2}-\mathrm{Ar}\right), 6.88,6.95$ $(2 \mathrm{~s}, 4 / 4 \mathrm{H}, \mathrm{Ar} H), 7.68-7.79(2 \mathrm{~m}, 8 \mathrm{H}, \mathrm{Phth}-H)$.

5,17-Di-t-butyl-11,23-diCMPOamido-26,28-diphthalimidopropoxy-25,27-dipropoxy-calix[4]arene $3 \mathrm{~b} . \quad p$ Nitrophenyl carbamoylmethyl diphenyl phosphine oxide (AE1, $0.25 \mathrm{~g}, 0.65 \mathrm{mmol}$ ) was added to a clear solution of ${ }_{40}$ diamine $2 \mathbf{b}(0.28 \mathrm{~g}, 0.27 \mathrm{mmol})$ and few drops of $\mathrm{NEt}_{3}$ in dichloromethane $(30 \mathrm{ml})$. The mixture was stirred at ambient temperature over night. The $p$-nitrophenol formed during the acylation was extracted with an aqueous solution of $\mathrm{NaOH}(5 \%, 3 \times 100 \mathrm{ml})$. After drying over $\mathrm{MgSO}_{4}$ the solvent was evaporated under reduced pressure, the residue was dissolved in dichloromethane $(5 \mathrm{ml})$. Compound $\mathbf{3 b}$ was obtained as white powder by reprecipitation from hexane; $0.4 \mathrm{~g}, 84 \%$; m.p. $194-196{ }^{\circ} \mathrm{C} ;{ }^{1} \mathrm{H}$ NMR $\left(200 \mathrm{MHz}, \mathrm{CDCl}_{3}\right) \delta 0.65\left(\mathrm{t}, 6 \mathrm{H},{ }^{3} \mathrm{~J}=7.3 \mathrm{~Hz}_{1}-\mathrm{CH}_{2}-\mathrm{CH}_{3}\right), 1.20$ ${ }_{45}\left(\mathrm{~m}, 22 \mathrm{H}, \mathrm{t}-\mathrm{Bu},-\mathrm{CH}_{2^{-}}\right), 1.51\left(\mathrm{~m}, 4 \mathrm{H},-\mathrm{CH}_{2^{-}}\right), 3.26-3.69\left(\mathrm{~m}, 24 \mathrm{H}, \mathrm{Ar}-\mathrm{CH}_{2}-\mathrm{Ar}, \mathrm{O}-\mathrm{CH}_{2^{-}},-\mathrm{CH}_{2}-\mathrm{P},-\mathrm{CH} 2^{-} \mathrm{N}\right), 6.90,6.95$ (2s, 8H, ArH), 7.40-7.75 (m, 28H, $\left.m, p-\mathrm{Ph}_{2} H, o-\mathrm{Ph}_{2} H, \mathrm{Pht}-H\right), 8.84$ (bs, 2H, NH); FD-MS, $\left(\mathrm{M}^{+}+\mathrm{H}\right) \mathrm{m} / \mathrm{z}=1508.9$.

5,17-Di-t-butyl-11,23-di-CMPOamido-26,28-diaminopropoxy-25,27-dipropoxy-calix[4]arene 4b. Hydrazine $(1.6 \mathrm{ml})$ was added to a solution of $3 \mathbf{b}(0.33 \mathrm{~g}, 0.2 \mathrm{mmol})$ in ethanol $(15 \mathrm{ml})$. After $2 \mathrm{~h}$ under reflux the reaction mixture was evaporated under reduced pressure; the residue was dissolved in chloroform (10 ml) and washed three ${ }_{50}$ times with water. The organic phase was dried over $\mathrm{MgSO}_{4}$ and evaporated. The desired diamine was obtained as white powder by reprecipitation from chloroform $(5 \mathrm{ml})$ and hexane $(25 \mathrm{ml}) .0 .25 \mathrm{~g}, 93 \%$; m.p. $212-214{ }^{\circ} \mathrm{C} ;{ }^{1} \mathrm{H} \mathrm{NMR}$ $\left(200 \mathrm{MHz}, \mathrm{DMSO}-\mathrm{d}_{6}\right) \delta 0.60\left(\mathrm{t}, 6 \mathrm{H},{ }^{3} \mathrm{~J}=6.8 \mathrm{~Hz},-\mathrm{CH}_{2}-\mathrm{CH}_{3}\right), 1.00\left(\mathrm{~m}, 4 \mathrm{H},-\mathrm{CH}_{2^{-}}\right), 1.19(\mathrm{~s}, 18 \mathrm{H}, \mathrm{t}-\mathrm{Bu}) 1.46(\mathrm{~m}, 4 \mathrm{H},-$ $\left.\mathrm{CH}_{2^{-}}\right), 3.22-4.03\left(\mathrm{~m}, 28 \mathrm{H}, \mathrm{NH}_{2}, \mathrm{Ar}-\mathrm{CH}_{2}-\mathrm{Ar}, \mathrm{O}-\mathrm{CH}_{2^{-}},-\mathrm{CH}_{2}-\mathrm{P},-\mathrm{CH}_{2}-\mathrm{N}\right), 6.98,7.23(2 \mathrm{~s}, 8 \mathrm{H}, \mathrm{ArH}), 7.55-7.92(\mathrm{~m}, 20 \mathrm{H}$, $\left.m, p-\mathrm{Ph}_{2} H, o-\mathrm{Ph}_{2} H\right), 10.24$ (bs, $\left.2 \mathrm{H}, \mathrm{NH}\right) ; \mathrm{FD}-\mathrm{MS},\left(\mathrm{M}^{+}+\mathrm{H}\right) \mathrm{m} / \mathrm{z}=1250.7$.

55 5,17-Di-t-butyl-11,23-diCMPOamido-26,28-diCMPOamidopropoxy-25,27-dipropoxy-calix[4] arene 5b. The tetra-CMPO $\mathbf{5 b}$ was prepared by the same acylation procedure described above for $\mathbf{3 b}$. Starting from a solution of diamine 4b (0.22 g, $0.14 \mathrm{mmol})$ in dichloromethane $(30 \mathrm{ml})$ and AE1 (0.16 g, $0.42 \mathrm{mmol})$, $5 \mathbf{b}$ was obtained as white 
powder, $0.2 \mathrm{~g}, 83 \%$; m.p. $152{ }^{\circ} \mathrm{C} ;{ }^{1} \mathrm{H} \mathrm{NMR}\left(400 \mathrm{MHz}, \mathrm{CDCl}_{3}\right) \delta 0.61\left(\mathrm{t}, 6 \mathrm{H},{ }^{3} \mathrm{~J}=7.7 \mathrm{~Hz},-\mathrm{CH}_{2}-\mathrm{CH}_{3}\right), 1.20(\mathrm{~m}, 22 \mathrm{H}$, $\left.\mathrm{t}-\mathrm{Bu},-\mathrm{CH}_{2^{-}}\right), 2.75\left(\mathrm{~m}, 4 \mathrm{H},-\mathrm{CH}_{2^{-}}\right), 2.72\left(\mathrm{t}, 4 \mathrm{H},{ }^{3} \mathrm{~J}=7.0 \mathrm{~Hz},-\mathrm{CH}_{2}-\mathrm{N}\right), 3.20\left(\mathrm{t}, 4 \mathrm{H},{ }^{3} \mathrm{~J}=7.3 \mathrm{~Hz}, \mathrm{O}-\mathrm{CH} 2^{-}\right), 3.50,3.56$ $\left(2 \mathrm{~d}, 8 \mathrm{H},{ }^{2} \mathrm{~J}=15.8 \mathrm{~Hz}, \mathrm{Ar}-\mathrm{CH}_{2}-\mathrm{Ar}\right), 3.61\left(\mathrm{~m}, 8 \mathrm{H}, \mathrm{O}-\mathrm{CH}_{2^{-}},-\mathrm{CH}_{2}-\mathrm{P}\right), 3.76\left(\mathrm{~d}, 4 \mathrm{H},{ }^{2} \mathrm{~J}=10.3 \mathrm{~Hz},-\mathrm{CH} \mathrm{H}_{2} \mathrm{P}\right), 6.87,7.09(2 \mathrm{~s}$, $8 \mathrm{H}, \mathrm{Ar} H), 7.38-7.81\left(\mathrm{~m}, 40 \mathrm{H}, m, p-\mathrm{Ph}_{2} \mathrm{H}, o-\mathrm{Ph}_{2} H\right), 8.96,10.05(2 \mathrm{bs}, 2 / 2 \mathrm{H}, \mathrm{NH}) ; \mathrm{FD}-\mathrm{MS},\left(\mathrm{M}^{+}+\mathrm{H}\right) \mathrm{m} / \mathrm{z}=1732.5$.

5,17-Di-t-butyl-11,23-diCMPOamido-26,28-diCMPOamidobutyloxy-25,27-dipropoxy-calix[4]arene 5c. TetraCMPO 5c was prepared as described for 5b. $100 \mathrm{mg}(0.078 \mathrm{mmol})$ diamine $\mathbf{8 c}$ in $10 \mathrm{ml}$ dichloromethane were acylated with and AE1 $(72 \mathrm{mg}, 0.18 \mathrm{mmol})$. After purification by column chromatography $\left(\mathrm{CHCl}_{3} / \mathrm{MeOH}^{98: 2)}\right.$ $0.138 \mathrm{~g}(87 \%)$ of $\mathbf{5 b}$ were obtained as pink powder; m.p. $152{ }^{\circ} \mathrm{C} ;{ }^{1} \mathrm{H} \mathrm{NMR}\left(400 \mathrm{MHz}, \mathrm{CDCl}_{3}\right) \delta 0.65\left(\mathrm{t}, 6 \mathrm{H},{ }^{3} \mathrm{~J}=7.7\right.$ $\left.\mathrm{Hz},-\mathrm{CH}_{2}-\mathrm{CH}_{3}\right), 1.01-1.23\left(\mathrm{~m}, 26 \mathrm{H}, \mathrm{t}-\mathrm{Bu}, 3 \mathrm{x}-\mathrm{CH}_{2}-\right), 2.93\left(\mathrm{t}, 4 \mathrm{H},{ }^{3} \mathrm{~J}=7.0 \mathrm{~Hz},-\mathrm{CH}_{2}-\mathrm{N}\right), 3.08,3.27\left(2 \mathrm{t}, 8 \mathrm{H},{ }^{3} \mathrm{~J}=7.3 \mathrm{~Hz}\right.$, $\left.{ }_{10} 2 \mathrm{xO}-\mathrm{CH}_{2}-\right), 3.37,3.67\left(2 \mathrm{~d}, 4 \mathrm{H},{ }^{2} \mathrm{~J}=14.3 \mathrm{~Hz}, \mathrm{CH}_{2} \mathrm{-P}\right), 3.65,3.69\left(2 \mathrm{~d}, 8 \mathrm{H},{ }^{2} \mathrm{~J}=15.5 \mathrm{~Hz}, \mathrm{Ar}-\mathrm{CH}_{2}-\mathrm{Ar}\right), 6.92,7.27(2 \mathrm{~s}$, $8 \mathrm{H}, \mathrm{Ar} H), 7.38-7.74\left(\mathrm{~m}, 40 \mathrm{H}, m, p-\mathrm{Ph}_{2} H, o-\mathrm{Ph}_{2} H\right), 8.31,10.20(2 \mathrm{bs}, 2 / 2 \mathrm{H}, \mathrm{N} H)$.

5,17-Di-t-butyl-11,23-dinitro-26,28-diaminopropoxy-25,27-dibutyloxy-calix[4]arene $6 \mathrm{c}$. $0.45 \mathrm{~g}(0.43 \mathrm{mmol})$ of the bis-phthalimide 1c were dissolved in $\mathrm{EtOH}(30 \mathrm{ml})$, hydrazine $(3 \mathrm{ml})$ was added and the reaction mixture was refluxed for $2 \mathrm{~h}$. After the usual work up the diamine 6c was obtained as yellow oil $(0.3 \mathrm{~g}, 81 \%)$. ${ }^{1} \mathrm{H}$ NMR (400 $\left.{ }_{15} \mathrm{MHz}_{2} \mathrm{CDCl}_{3}\right) \delta 0.80\left(\mathrm{t}, 6 \mathrm{H},{ }^{3} \mathrm{~J}=7.4 \mathrm{~Hz},-\mathrm{CH}_{2}-\mathrm{CH}_{3}\right), 1.23\left(\mathrm{~m}, 22 \mathrm{H}, t-\mathrm{Bu},-\mathrm{CH}_{2^{-}}\right), 1.47\left(\mathrm{~m}, 4 \mathrm{H},-\mathrm{CH} 2^{-}\right), 2.28(\mathrm{bs}, 4 \mathrm{H},-$ $\mathrm{NH}_{2}$ ), 2.69 (bt, 4H, $\left.-\mathrm{CH}_{2^{-}}\right), 3.51\left(\mathrm{t}, 4 \mathrm{H},{ }^{3} \mathrm{~J}=7.4 \mathrm{~Hz}, \mathrm{~N}-\mathrm{CH}_{2^{-}}\right) 3.59\left(\mathrm{bt}, 4 \mathrm{H}, \mathrm{O}-\mathrm{CH}_{2^{-}}\right), 3.63,3.71\left(2 \mathrm{~d}, 4 / 4 \mathrm{H},{ }^{2} \mathrm{~J}=15.2\right.$ $\left.\mathrm{Hz}, \mathrm{Ar}-\mathrm{CH}_{2}-\mathrm{Ar}\right), 6.98,7.94(2 \mathrm{~s}, 4 / 4 \mathrm{H}, \mathrm{ArH})$.

5,17-Di-t-butyl-11,23-dinitro-26,28-diCMPOamidobutyloxy-25,27-dipropoxy-calix[4]arene 7c. The acylation of diamine 6c by AE1 was carried out at rt over night as follows: $0.3 \mathrm{~g} 6 \mathbf{c}(0.35 \mathrm{mmol})$ dissolved in dichloromethane ${ }_{20}(15 \mathrm{ml})$ were reacted with $0.32 \mathrm{~g}(0.84 \mathrm{mmol}) \mathbf{A E 1} ; 0.35 \mathrm{~g}(75 \%)$ of diCMPOamide 7c were obtained as white powder; m.p. $142{ }^{\circ} \mathrm{C} ;{ }^{1} \mathrm{H}$ NMR $\left(400 \mathrm{MHz} \mathrm{CDCl}_{3}\right) \delta 0.80\left(\mathrm{t}, 6 \mathrm{H},{ }^{3} \mathrm{~J}=7.4 \mathrm{~Hz},-\mathrm{CH}_{2}-\mathrm{CH}_{3}\right), 1.22(\mathrm{~m}, 26 \mathrm{H}, \mathrm{t}-\mathrm{Bu}, 2 \mathrm{x}-$ $\left.\mathrm{CH}_{2^{-}}\right), 3.13\left(\mathrm{~m}, 4 \mathrm{H},-\mathrm{CH}_{2^{-}}\right), 3.07$ (bt, 4H, $\left.-\mathrm{CH}_{2}-\mathrm{N}\right), 3.48\left(2 \mathrm{t}, 4 / 4 \mathrm{H}, 2 \mathrm{x} \mathrm{O}-\mathrm{CH}_{2^{-}}\right), 3.66\left(\mathrm{~d}, 4 \mathrm{H},{ }^{2} \mathrm{~J}=13.7 \mathrm{~Hz},-\mathrm{CH} 2^{-} \mathrm{P}\right)$, $3.66,3.75\left(2 \mathrm{~d}, 8 \mathrm{H},{ }^{2} \mathrm{~J}=15.2 \mathrm{~Hz}, \mathrm{Ar}-\mathrm{CH}_{2}-\mathrm{Ar}\right), 6.96,7.88(2 \mathrm{~s}, 4 / 4 \mathrm{H}, \mathrm{Ar} H), 7.38-7.81\left(\mathrm{~m}, 22 \mathrm{H}, m, p-\mathrm{Ph}_{2} H, o-\mathrm{Ph}_{2} H\right.$, $\mathrm{N} H)$.

5,17-Di-t-butyl-11,23-diamino-26,28-diCMPOamidobutyloxy-25,27-dipropoxy-calix[4]arene 8c. A solution of 7c $(110 \mathrm{mg}, 0.082 \mathrm{mmol})$ and hydrazine $(1 \mathrm{ml})$ in ethanol $(15 \mathrm{ml})$ was refluxed for $2 \mathrm{~h}$ with Raney/Ni as catalyst. The solvent was evaporated under reduced pressure; the formed residue was dissolved in chloroform (10 $\mathrm{ml})$ and washed three times with water. The organic phase was dried over $\mathrm{MgSO}_{4}$, the solvent was evaporated under reduced pressure. The diamine 8c was obtained as yellow oil which was used in the next step without further purification.

5,17-Di-t-butyl-11,23-dinitro-26,28-dipicolinamidopropoxy-25,27-dipropoxy-calix[4]arene 9b. The active ester AE2 $(0.21 \mathrm{~g}, 0.73 \mathrm{mmol})$ was added to a suspension of diamine $6 \mathbf{b}(0.25 \mathrm{~g}, 0.3 \mathrm{mmol})$ in chloroform (30 ml). The mixture was stirred at room temperature until the tlc shows that no starting material was left. The pentafluorophenol formed during the reaction was extracted with a solution of $\mathrm{Na}_{2} \mathrm{CO}_{3}(5 \%, 4 \times 100 \mathrm{ml})$ and the organic phase was dried over $\mathrm{MgSO}_{4}$. The solvent was evaporated under reduced pressure, the residue was dissolved in dichloromethane ${ }_{35}(5 \mathrm{ml})$ from which the desired compound was obtained by reprecipitation with hexane as yellow powder; $0.2 \mathrm{~g}(64$ $\%)$; m.p. $127-129{ }^{\circ} \mathrm{C} ;{ }^{1} \mathrm{H}$ NMR $\left(300 \mathrm{MHz}, \mathrm{CDCl}_{3}\right) \delta 0.78\left(\mathrm{t}, 6 \mathrm{H},{ }^{3} \mathrm{~J}=7.35 \mathrm{~Hz},-\mathrm{CH}_{2}-\mathrm{CH}_{3}\right), 1.21(\mathrm{~s}, 18 \mathrm{H}, \mathrm{t}-\mathrm{Bu}), 1.41$ $\left(\mathrm{m}, 4 \mathrm{H},-\mathrm{CH}_{2}-\mathrm{CH}_{2}-\mathrm{CH}_{2}-\right), 1.71\left(\mathrm{~m}, 4 \mathrm{H},-\mathrm{CH}_{2}-\mathrm{CH}_{3}\right), 3.45-3.50\left(\mathrm{~m}, 8 \mathrm{H},-\mathrm{CH}_{2}-\mathrm{N}, \mathrm{O}-\mathrm{CH}_{2}-\right), 3.65-3.81\left(\mathrm{~m}, 12 \mathrm{H}, \mathrm{Ar}-\mathrm{CH}_{2}-\right.$ Ar, O-CH $\left.2^{-}\right), 6.95(\mathrm{~s}, 4 \mathrm{H}, \mathrm{ArH}), 7.40\left(\mathrm{~m}, 2 \mathrm{H}, H_{b}\right), 7.80\left(\mathrm{~m}, 2 \mathrm{H}, H_{c}\right), 7.99(\mathrm{~s}, 4 \mathrm{H}, \mathrm{Ar} H), 8.17\left(\mathrm{~m}, 2 \mathrm{H}, H_{d}\right), 8.29(\mathrm{bt}$, $2 \mathrm{H},-\mathrm{N} H), 8.58\left(\mathrm{~m}, 2 \mathrm{H}, H_{a}\right)$.

5,17-Di-t-butyl-11,23-dinitro-26,28-dipicolylamidobutyloxy-25,27-dipropoxy-calix[4]arene 9c. Starting from diamine $6 \mathbf{c}(0.25 \mathrm{~g})$, containing traces of compounds which has unhydrogenated allyl groups the desired compound 9c was obtained as the analogous mixture with the respective allyl compounds as described for $9 \mathbf{b} ; 0.25 \mathrm{~g}(83 \%)$ were isolated as a white powder. The signals belonging to the protons of $9 \mathrm{c}$ are listed below. ${ }^{1} \mathrm{H} \mathrm{NMR}\left(300 \mathrm{MHz}, \mathrm{CDCl}{ }_{3}\right) \delta$ $0.84\left(\mathrm{t}, 6 \mathrm{H},{ }^{3} \mathrm{~J}=7.35 \mathrm{~Hz},-\mathrm{CH}_{2}-\mathrm{CH}_{3}\right), 1.21(\mathrm{~s}, 18 \mathrm{H}, \mathrm{t}-\mathrm{Bu}), 1.20-1.66\left(\mathrm{~m}, 12 \mathrm{H},-\mathrm{CH}_{2}-\mathrm{CH}_{2^{-}}-\mathrm{CH}_{2^{-}}-\mathrm{CH}_{2^{-}},-\mathrm{CH}_{2}-\mathrm{CH}_{3}\right)$, ${ }_{45} 3.46-3.86\left(\mathrm{~m}, 2 \mathrm{H},-\mathrm{CH}_{2}-\mathrm{N}, 2 \mathrm{x} \mathrm{O}-\mathrm{CH}_{2^{-}}, \mathrm{Ar}-\mathrm{CH}_{2}-\mathrm{Ar}\right), 6.96(\mathrm{~s}, 4 \mathrm{H}, \mathrm{ArH}), 7.39\left(\mathrm{~m}, 2 \mathrm{H}, H_{b}\right), 7.81\left(\mathrm{~m}, 2 \mathrm{H}, H_{c}\right), 7.92(\mathrm{~s}$, $4 \mathrm{H}, \operatorname{Ar} H), 8.20\left(\mathrm{~m}, 2 \mathrm{H}, H_{d}\right), 8.25(\mathrm{bt}, 2 \mathrm{H},-\mathrm{NH}), 8.56\left(\mathrm{~m}, 2 \mathrm{H}, H_{a}\right)$.

5,17-Di-t-butyl-11,23-diamino-26,28-di-picolinamidopropyloxy-25,27-dipropoxy-calix[4]arene 10b. Raney/Ni was added to a clear solution of $\mathbf{9 b}(740 \mathrm{mg}, 0.70 \mathrm{mmol})$ in THF $(20 \mathrm{ml})$, and the reaction mixture was stirred under hydrogen during 4 days. When the hydrogen uptake was complete the catalyst was filtered off and the solvent ${ }_{50}$ evaporated under reduced pressure. The residue was dissolved in chloroform $(10 \mathrm{ml})$ and the desired amine was precipitated with hexane $(15 \mathrm{ml})$ as a white powder, $200 \mathrm{mg}, 31 \%$; m.p. $120{ }^{\circ} \mathrm{C}$; ${ }^{1} \mathrm{H} \mathrm{NMR}(300 \mathrm{MHz} \mathrm{CDCl})_{3} \delta 0.59$ $\left(\mathrm{t}, 6 \mathrm{H},{ }^{3} \mathrm{~J}=7.7 \mathrm{~Hz},-\mathrm{CH}_{2}-\mathrm{CH}_{3}\right), 1.01-1.08\left(\mathrm{~m}, 4 \mathrm{H},-\mathrm{CH}_{2^{-}}\right), 1.22(\mathrm{~s}, 18 \mathrm{H}, \mathrm{t}-\mathrm{Bu}), 1.55-1.59\left(\mathrm{~m}, 4 \mathrm{H},-\mathrm{CH} 2^{-}\right), 2.89(\mathrm{bs}$, $\left.4 \mathrm{H},-\mathrm{NH}_{2}\right), 3.17-3.22\left(\mathrm{~m}, 8 \mathrm{H},-\mathrm{CH}_{2}-\mathrm{N},-\mathrm{CH}_{2}-\mathrm{O}\right), 3.51\left(\mathrm{t}, 4 \mathrm{H},{ }^{3} \mathrm{~J}=7.3 \mathrm{~Hz}, \mathrm{O}-\mathrm{CH}_{2^{-}}\right), 3.65,3.74\left(2 \mathrm{~d}, 4 / 4 \mathrm{H},{ }^{2} \mathrm{~J}=15.8 \mathrm{~Hz}\right.$, Ar- $\left.\mathrm{CH}_{2}-\mathrm{Ar}\right), 6.48,6.92(2 \mathrm{~s}, 4 / 4 \mathrm{H}, \mathrm{ArH}), 7.38\left(\mathrm{~m}, 2 \mathrm{H}, H_{b}\right), 7.80\left(\mathrm{~m}, 2 \mathrm{H}, H_{c}\right), 8.13\left(\mathrm{~m}, 2 \mathrm{H}, H_{d}\right), 8.26(\mathrm{bt}, 2 \mathrm{H},-\mathrm{NH})$, ${ }_{55} 8.51\left(\mathrm{~m}, 2 \mathrm{H}, H_{a}\right)$.

5,17-Di-t-butyl-11,23-diamino-26,28-dipicolinamidobutyloxy-25,27-dipropoxy-calix[4]arene 10c. Diamine 10c was prepared analogously. For a solution of mixture $9 \mathbf{c}(0.25 \mathrm{~g})$ in THF $(20 \mathrm{ml})$ the hydrogenation was complete after 30 h. The diamine was reprecipitated from chloroform/hexane ( 20 ml, 1:3) as white powder, $220 \mathrm{mg}, 93 \%$; m.p.132 
${ }^{\circ} \mathrm{C} ;{ }^{1} \mathrm{H}$ NMR $\left(300 \mathrm{MHz}, \mathrm{CDCl}_{3}\right) \delta 0.64\left(\mathrm{t}, 6 \mathrm{H},{ }^{3} \mathrm{~J}=7.7 \mathrm{~Hz},-\mathrm{CH}_{2}-\mathrm{CH}_{3}\right), 1.09-1.22\left(\mathrm{~m}, 26 \mathrm{H}, 2 \mathrm{x}-\mathrm{CH} 2^{-}, \mathrm{t}-\mathrm{Bu}\right), 1.82-1.86$ $\left(\mathrm{m}, 4 \mathrm{H},-\mathrm{CH}_{2^{-}}\right), 3.21-3.73\left(\mathrm{~m}, 2 \mathrm{H},-\mathrm{CH}_{2}-\mathrm{N},-\mathrm{CH}_{2}-\mathrm{O}, \mathrm{Ar}-\mathrm{CH}_{2}-\mathrm{Ar}\right), 6.42\left(\mathrm{~s}, 4 \mathrm{H},-\mathrm{NH}_{2}\right), 6.92,6.97(2 \mathrm{~s}, 4 / 4 \mathrm{H}, \mathrm{ArH})$, $7.38\left(\mathrm{~m}, 2 \mathrm{H}, H_{b}\right), 7.81\left(\mathrm{~m}, 2 \mathrm{H}, H_{c}\right), 8.18\left(\mathrm{~m}, 2 \mathrm{H}, H_{d}\right), 8.30(\mathrm{bt}, 2 \mathrm{H},-\mathrm{N} H), 8.54\left(\mathrm{~m}, 2 \mathrm{H}, H_{a}\right)$.

5,17-Di-t-butyl-11,23-diCMPO-26,28-dipicolinamidopropyloxy-25,27-dipropoxy-calix[4]arene 11b. The final acylation was done as described above e.g. for $\mathbf{6 b} .200 \mathrm{mg}$ of diamine $\mathbf{1 0 b}(0.20 \mathrm{mmol})$ dissolved in dichloromethane $(30 \mathrm{ml})$ were reacted with $490 \mathrm{mg}(2.4 \mathrm{mmol})$ of active ester AE1. $170 \mathrm{mg}$ of 11b $(65 \%)$ were isolated as white powder; m.p. $108-109{ }^{\circ} \mathrm{C}$; ${ }^{1} \mathrm{H}$ NMR $\left(300 \mathrm{MHz}, \mathrm{DMSO}-\mathrm{d}_{6}\right) \delta 0.93\left(\mathrm{t}, 6 \mathrm{H},{ }^{3} \mathrm{~J}=7.2 \mathrm{~Hz},-\mathrm{CH}_{2}-\mathrm{CH}_{3}\right), 1.18(\mathrm{~s}, 18 \mathrm{H}, \mathrm{t}-\mathrm{Bu})$, $1.44\left(\mathrm{~m}, 4 \mathrm{H},-\mathrm{CH}_{2}-\right), 3.05-3.78\left(\mathrm{~m}, 24 \mathrm{H},-\mathrm{CH}_{2}-\mathrm{N},-\mathrm{CH}_{2}-\mathrm{O}, \mathrm{Ar}-\mathrm{CH}_{2}-\mathrm{Ar},-\mathrm{CH}_{2}-\mathrm{P}\right), 6.32(\mathrm{~s}, 2 \mathrm{H},-\mathrm{NH}), 6.95,7.12(2 \mathrm{~s}$, 4/4H, $\mathrm{Ar} H$ ), 7.49-7.99 (m, 22H, m, p- $\left.\mathrm{Ph}_{2} H, o-\mathrm{Ph}_{2} H, H_{b}\right), 8.34\left(\mathrm{~m}, 2 \mathrm{H}, H_{c}\right), 8.50\left(\mathrm{~m}, 2 \mathrm{H}, H_{d}\right), 8.73(\mathrm{bt}, 2 \mathrm{H},-\mathrm{N} H$,$) ,$ $109.77\left(\mathrm{~m}, 2 \mathrm{H}, H_{a}\right)$.

5,17-Di-t-butyl-11,23-diCMPO-26,28-dipicolinamidobutyloxy-25,27-dipropoxy-calix[4]arene $11 \mathrm{c} .220 \quad \mathrm{mg}$ diamine 10c $(0.23 \mathrm{mmol})$ in dichloromethane $(30 \mathrm{ml})$ were reacted analogously with $325 \mathrm{mg}(0.55 \mathrm{mmol})$ AE1 to yield $160 \mathrm{mg}(47 \%)$ of 11c as white powder; m.p. $117-119{ }^{\circ} \mathrm{C} ;{ }^{1} \mathrm{H}$ NMR $\left(200 \mathrm{MHz}, \mathrm{DMSO}-\mathrm{d}_{6}\right) \delta 0.60\left(\mathrm{t}, 6 \mathrm{H},{ }^{3} J=7.2\right.$ $\left.\mathrm{Hz},-\mathrm{CH}_{2}-\mathrm{CH}_{3}\right), 1.21\left(\mathrm{~m}, 30 \mathrm{H}, \mathrm{t}-\mathrm{Bu},-\mathrm{CH}_{2}-\right), 3.06-3.72\left(\mathrm{~m}, 24 \mathrm{H},-\mathrm{CH}_{2}-\mathrm{N},-\mathrm{CH}_{2}-\mathrm{O}, \mathrm{Ar}-\mathrm{CH}_{2}-\mathrm{Ar},-\mathrm{CH} \mathrm{H}_{2}-\mathrm{P}\right), 6.90,7.06$ $15(2 \mathrm{~s}, 4 / 4 \mathrm{H}, \mathrm{Ar} H), 7.40-7.80\left(\mathrm{~m}, 22 \mathrm{H}, m, p-\mathrm{Ph}_{2} H, o-\mathrm{Ph}_{2} H, H_{b}\right), 8.11\left(\mathrm{~m}, 2 \mathrm{H}, H_{c}\right), 8.34-8.50\left(\mathrm{~m}, 6 \mathrm{H}, H_{d},-\mathrm{N} H, H_{a}\right), 9.45$ $(\mathrm{s}, 2 \mathrm{H}, \mathrm{NH})$.

5,17-Di-t-butyl-11,23-dinitro-25,27-diallyloxy-26,28-diethoxycarbonylmethoxy-calix[4]arene $13 \quad(1,3-$ alternate) and 13a (partial cone). A stirred suspension of dinitro-calixarene $12(1.3 \mathrm{~g}, 1.6 \mathrm{mmol})$ and $\mathrm{Cs}_{2} \mathrm{CO}_{3}(4 \mathrm{~g}$ $12.8 \mathrm{mmol})$ in dry DMF $(40 \mathrm{ml})$ was heated to $40{ }^{\circ} \mathrm{C}$ under nitrogen. After $1 \mathrm{~h}$ allylbromide $(1.1 \mathrm{ml}, 12.8 \mathrm{mmol}) \mathrm{was}$ 20 added and the reaction was continued for 7 days. The DMF was removed under reduced pressure and the residue was treated with chloroform $(25 \mathrm{ml})$ and water $(75 \mathrm{ml})$. The organic phase was washed with water $(2 \times 75 \mathrm{ml})$, dried $\left(\mathrm{MgSO}_{4}\right)$ and the solvent was evaporated to give a yellow oil. Analysis by t.l.c showed the presence of two compounds, which were separated and purified by column chromatography $\left(\mathrm{CHCl}_{3}\right)$ and identified by NMR as the 1,3-alternate and the partial cone isomers.

2513 (1,3-alternate): White-yellow crystals, yield $0.3 \mathrm{~g}, 21 \%$; $\mathrm{mp} 199-201{ }^{\circ} \mathrm{C} ;{ }^{1} \mathrm{H} \mathrm{NMR}\left(300 \mathrm{MHz}, \mathrm{CDCl}_{3}\right) \delta 1.24(\mathrm{t}$, $\left.6 \mathrm{H},{ }^{3} \mathrm{~J}=6.1 \mathrm{~Hz},-\mathrm{CH}_{2}-\mathrm{CH}_{3}\right), 1.24(\mathrm{~s}, 18 \mathrm{H}, t-\mathrm{Bu}), 3.66,4.07\left(2 \mathrm{~d}, 4 / 4 \mathrm{H},{ }^{2} \mathrm{~J}=14.7,15.1 \mathrm{~Hz}, \mathrm{Ar}-\mathrm{CH} \mathrm{H}_{2}-\mathrm{Ar}\right), 3.99(\mathrm{~s}, 4 \mathrm{H},-$ $\left.\mathrm{CH}_{2}-\mathrm{O}-\right), 4.19\left(\mathrm{~m}, 8 \mathrm{H}, \mathrm{O}-\mathrm{CH}_{2}\right), 5.14\left(\mathrm{~m}, 4 \mathrm{H}, \mathrm{CH}_{2}=\mathrm{CH}-\right), 5.78\left(\mathrm{~m}, 2 \mathrm{H}, \mathrm{CH}_{2}=\mathrm{CH}-\right), 6.98,8.02(2 \mathrm{~s}, 4 / 4 \mathrm{H}, \mathrm{ArH})$.

13a (partial cone): Yellow powder, yield $0.54 \mathrm{~g}, 39 \%$; mp 222-223 ${ }^{\circ} \mathrm{C} ;{ }^{1} \mathrm{H}$ NMR $\left(300 \mathrm{MHz}, \mathrm{CDCl}_{3}\right) \delta 1.00(\mathrm{~s}$, $18 \mathrm{H}, t-\mathrm{Bu}), 1.31\left(\mathrm{t}, 6 \mathrm{H},{ }^{3} \mathrm{~J}=7.3 \mathrm{~Hz}-\mathrm{CH}_{2}-\mathrm{CH}_{3}\right), 3.22,3.65,4.07\left(3 \mathrm{~d}, 2 / 2 / 2 \mathrm{H},{ }^{2} \mathrm{~J}=13.6,13.9,13.6 \mathrm{~Hz}, \mathrm{Ar}-\mathrm{CH} \mathrm{H}_{2}-\mathrm{Ar}\right)$, ${ }_{30} 4.15-4.37\left(\mathrm{~m}, 14 \mathrm{H}, 3 \mathrm{xO}-\mathrm{CH}_{2^{-}}, \mathrm{Ar}-\mathrm{CH}_{2}-\mathrm{Ar}\right), 4.94,5.40\left(2 \mathrm{~m}, 2 / 2 \mathrm{H},--\mathrm{CH}=\mathrm{CH}_{2}\right), 6.06,6.12\left(2 \mathrm{~m}, 2 / 2 \mathrm{H},-\mathrm{CH}^{2} \mathrm{CH}_{2}\right)$, $6.50,6.88\left(2 \mathrm{~d}, 2 / 2 \mathrm{H},{ }^{4} \mathrm{~J}=2.5,2.5 \mathrm{~Hz}, \mathrm{ArH}\right), 8.03,8.37(2 \mathrm{~s}, 2 / 2 \mathrm{H}, \mathrm{Ar} H)$.

5,17-Di-t-butyl-11,23-diCMPO-25,27-dipropoxy-26,28-diethoxycarbonylmethoxy-calix[4]arene 15 . $\mathrm{Pd} / \mathrm{C}(0.1$ g) was added to a solution of the dinitro compound $\mathbf{1 3}(0.3 \mathrm{~g}, 0.34 \mathrm{mmol})$ in THF (15 ml) and the suspension was stirred under hydrogen atmosphere at rt. After the hydrogen uptake was complete, the catalyst was filtered off and the 35 solvent was evaporated. The residue was dissolved in dichloromethane $(15 \mathrm{ml})$ to form a clear solution. AE1 (80 mg, $0.09 \mathrm{mmol}$ ) and few drops of triethylamine were added, and the mixture was stirred at $\mathrm{rt}$ for $12 \mathrm{~h}$. An aqueous solution of $\mathrm{NaOH}(30 \mathrm{ml}, 5 \%)$ was added and the stirring was continued for additional 30 min. Then the organic phase was separated, washed three times with diluted aqueous $\mathrm{NaOH}(3 \times 30 \mathrm{ml})$, dried over $\mathrm{MgSO}_{4}$ and evaporated under reduced pressure. The product was reprecipitated from $\mathrm{CHCl}_{3} /$ hexane $(15 \mathrm{ml}, 1: 2)$ to give $0.11 \mathrm{~g}(92 \%)$ of a 40 white powder; m.p. $210-212{ }^{\circ} \mathrm{C} ;{ }^{1} \mathrm{H}$ NMR $\left(300 \mathrm{MHz}, \mathrm{CDCl}_{3}\right) \delta 0.73,1.13\left(2 \mathrm{t}, 6 / 6 \mathrm{H},{ }^{3} \mathrm{~J}=7.7,7.3 \mathrm{~Hz}, 2 \mathrm{x}-\mathrm{CH}_{2}-\mathrm{CH}_{3}\right)$, $1.20\left(\mathrm{~m}, 22 \mathrm{H}, \mathrm{t}-\mathrm{Bu},-\mathrm{CH}_{2^{-}}\right), 3.35,4.01\left(2 \mathrm{t}, 4 / 4 \mathrm{H},{ }^{3} \mathrm{~J}=7.7,6.99 \mathrm{~Hz}, 2 \mathrm{xO}-\mathrm{CH}_{2^{-}}\right), 3.44\left(\mathrm{~d}, 4 \mathrm{H},{ }^{2} \mathrm{~J}=12.9 \mathrm{~Hz},-\mathrm{CH} \mathrm{2}^{-} \mathrm{P}\right)$, 3.57 (s, 4H, O-CH $\left.2^{-}\right), 3.64,3.93\left(2 \mathrm{~d}, 4 / 4 \mathrm{H},{ }^{2} \mathrm{~J}=15.8 \mathrm{~Hz}, \mathrm{Ar}-\mathrm{CH}_{2}-\mathrm{Ar}\right), 6.92,7.15(2 \mathrm{~s}, 4 / 4 \mathrm{H}, \mathrm{ArH}), 7.43-7.78(\mathrm{~m}, 20 \mathrm{H}$, $\left.m, p-\mathrm{Ph}_{2} \mathrm{H}, o-\mathrm{Ph}_{2} H\right), 9.06(\mathrm{bs}, 2 \mathrm{H}, \mathrm{N} H)$.

5,17-Di-t-butyl-11,23-diCMPO-25,27-dipropoxy-26,28-dicarboxymethoxy-calix[4]arene 16 . An aqueous ${ }_{45}$ solution of $\mathrm{LiOH}(98 \mathrm{mg} / 2 \mathrm{ml}$ water $)$ was added to the solution of $\mathbf{1 5}(0.11 \mathrm{~g}, 0.09 \mathrm{mmol})$ in $\mathrm{THF}(7 \mathrm{ml})$ and $\mathrm{MeOH}$ $(4 \mathrm{ml})$ and the mixture was stirred at $\mathrm{rt}$ over night and neutralized with diluted $\mathrm{HCl}$. The desired acid was isolated by precipitation with water. The white precipitate was filtered and washed with water and dried. $0.1 \mathrm{~g}(96 \%)$ of diacid 16 were obtained as white powder; m.p. $264{ }^{\circ} \mathrm{C} ;{ }^{1} \mathrm{H}$ NMR $\left(400 \mathrm{MHz}, \mathrm{DMSO}-\mathrm{d}_{6}\right) \delta 0.65\left(\mathrm{t}, 6 \mathrm{H},{ }^{3} \mathrm{~J}=7.4 \mathrm{~Hz},-\mathrm{CH}_{2}-\right.$ $\left.\mathrm{CH}_{3}\right), 1.15\left(\mathrm{~m}, 4 \mathrm{H},-\mathrm{CH}_{2}-\mathrm{CH}_{3}\right), 1.23(\mathrm{~s}, 18 \mathrm{H}, \mathrm{t}-\mathrm{Bu}), 1.96(\mathrm{~s}, 2 \mathrm{H},-\mathrm{COOH}), 3.31\left(\mathrm{t}, 4 \mathrm{H},{ }^{3} \mathrm{~J}=7.4 \mathrm{~Hz}, \mathrm{O}-\mathrm{CH} 2^{-}\right), 3.67$, ${ }_{50} 3.92\left(2 \mathrm{~d}, 4 / 4 \mathrm{H},{ }^{2} \mathrm{~J}=16.2 \mathrm{~Hz}, \mathrm{Ar}-\mathrm{CH}_{2}-\mathrm{Ar}\right), 3.76\left(\mathrm{~d}, 4 \mathrm{H},{ }^{2} \mathrm{~J}=16.0 \mathrm{~Hz},-\mathrm{CH}_{2}-\mathrm{P}\right), 3.69$ (s, 4H, O-CH - ) $7.00,7.16(2 \mathrm{~s}$, 4/4H, $\mathrm{Ar} H$ ), 7.51-7.84 (m, 20H, $m, p-\mathrm{Ph}_{2} H, o-\mathrm{Ph}_{2} H$ ), 9.46 (bs, 2H, NH).

Binding studies. Extraction experiments of lanthanide and thorium nitrates $\left(\mathrm{C}_{\mathrm{M}}=10^{-4} \mathrm{M}\right)$ from $1 \mathrm{M}$ nitric acid into dichloromethane were performed at $20{ }^{\circ} \mathrm{C}$. A colorimetric method using Arsenazo-III was applied to determine the ${ }_{55}$ concentration of the metal ions before and after extraction in the aqueous phase. The full procedure, the starting materials and the calculations of the distribution coefficients (D) and the percentage extraction (\% E) have already been described in detail. ${ }^{3}$ Complexation data, i.e. the stoichiometry and the stability constants $(\log \beta)$ of the species formed in methanol, were derived from spectrophotometric titrations at $25{ }^{\circ} \mathrm{C}$. The experimental procedure ${ }^{30}$ and the 
data processing by program Specfit ${ }^{31}$ have been previously published. The ligand concentrations were ranging between $5 \times 10^{-5}$ and $10^{-4} \mathrm{M}$ and the ionic strength was settled as constant by using $10^{-2} \mathrm{M} \mathrm{Et}_{4} \mathrm{NNO}_{3}$ as backgroundelectrolyte.

Stock solutions of lanthanide and thorium nitrates used in extraction and complexation experiments were ${ }_{5}$ standardized by complexometric titrations with EDTA in the presence of xylenol orange as coloured indicator.

Crystallographic data. Single crystals were obtained from a solution in acetone/methanol (1)') or chloroform/methanol $(\mathbf{1 3}, \mathbf{1 7}, \mathbf{1 8})$ which was overlaid in a test tube by an excess of methanol. The two molecules of water found per molecule $\mathbf{1 8}$ in its crystal structure were obviously uptaken from the atmosphere.

10 Intensity data were collected on a STOE IPDS II two-circle diffractometer with graphite-monochromated $\mathrm{MoK}_{\alpha}$ radiation at $173 \mathrm{~K}$. For $\mathbf{1 3}$ and $\mathbf{1 7}$ an empirical absorption correction was performed using the MULABS ${ }^{32}$ option in PLATON. ${ }^{33}$ The structures were solved by direct methods using the program SHELXS ${ }^{34}$ and refined against $F^{2}$ with

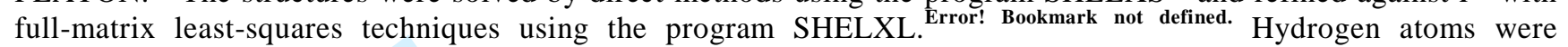
included at calculated positions with fixed displacement parameters. In 1b', one tert-butyl group is disordered over ${ }_{15}$ two positions (site occupation factors $0.491(6) / 0.509(6)$ ). In 13, the two tert-butyl groups (site occupation factors $0.449(6) / 0.551(5)$ and $0.320(2) / 0.680(2))$ and the terminal two $\mathrm{C}$ atoms of a propenoxy group (site occupation factors $0.40(2) / 0.60(2))$ are disordered over two positions. The C-C bond lengths in the disordered tert-butyl groups were restrained to $1.54(1) \AA$ and the $\mathrm{C}=\mathrm{C}$ double bonds in the propenoxy groups to $1.30(1) \AA$. In $\mathbf{1 8}$, the water $\mathrm{H}$ atoms could not be located and were omitted from refinement. The geometric parameters of the side chain O32 to N324 20 were restrained to be equal to those of O12 to N124.

Crystallographic data in CIF format have been deposited with the Cambridge Crystallographic Data Centre: reference numbers: 1b' CCDC 734171; 13 CCDC 734172; 17 CCDC 734173; 18 CCDC 734174. 
Table 4 Crystal Data and Structure Refinement Details for 1b', 13, 17 and 18; data collection with a Stoe-IPDS-II two-circlediffractometer, solution and refinement with SHELXS and SHELXL.

\begin{tabular}{|c|c|c|c|c|}
\hline Compound & 1b' & 13 & 17 & 18 \\
\hline empirical formula & $\begin{array}{c}\mathrm{C}_{64} \mathrm{H}_{68} \mathrm{~N}_{4} \mathrm{O}_{12} \\
\mathrm{CH}_{3} \mathrm{COCH}_{3}\end{array}$ & $\mathrm{C}_{50} \mathrm{H}_{58} \mathrm{~N}_{2} \mathrm{O}_{12} \cdot \mathrm{CHCl}_{3}$ & $\mathrm{C}_{56} \mathrm{H}_{52} \mathrm{Cl}_{3} \mathrm{~N}_{4} \mathrm{O}_{12} \cdot \mathrm{CHCl}_{3}$ & $\mathrm{C}_{68} \mathrm{H}_{78} \mathrm{~N}_{2} \mathrm{O}_{8} \cdot 2 \mathrm{H}_{2} \mathrm{O}$ \\
\hline color & colourless & Colourless & light yellow & colourless \\
\hline shape & block & Block & block & block \\
\hline fw $[\mathrm{g} / \mathrm{mol}]$ & 1143.30 & 998.35 & 1092.38 & 1087.36 \\
\hline temperature $[\mathrm{K}]$ & 173 & 173 & 100 & 173 \\
\hline wave length $[\AA]$ & 0.71073 & 0.71073 & 0.71073 & 0.71073 \\
\hline crystal system & triclinic & triclinic & triclinic & monoclinic \\
\hline space group & P-1 & P-1 & P-1 & $\mathrm{P} 2{ }_{1} / \mathrm{c}$ \\
\hline Z & 2 & 2 & 2 & 4 \\
\hline \multicolumn{5}{|l|}{ cell parameters } \\
\hline $\mathrm{a}[\AA]$ & $12.924(3)$ & $10.4879(6)$ & $9.8020(7)$ & $13.0264(9)$ \\
\hline $\mathrm{b}[\AA]$ & $14.094(3)$ & $14.0724(8)$ & $15.6199(11)$ & $24.5795(15)$ \\
\hline$c[\AA]$ & $17.881(4)$ & $19.2015(11)$ & 17.9197(13) & $19.9439(16)$ \\
\hline$\alpha\left[^{\circ}\right]$ & $78.44(3)$ & $96.336(4)$ & $72.276(6)$ & 90 \\
\hline$\beta\left[^{\circ}\right]$ & $87.30(3)$ & $104.191(4)$ & $88.546(6)$ & $105.126(6)$ \\
\hline$\gamma\left[{ }^{\mathrm{O}}\right]$ & $70.72(3)$ & $111.084(4)$ & $88.444(6)$ & 90 \\
\hline Volume $\left[\AA^{3}\right]$ & $3011.5(10)$ & $2501.0(2)$ & $2612.0(3)$ & $6164.4(8)$ \\
\hline calcd density $\left[\mathrm{Mg} / \mathrm{m}^{3}\right]$ & 1.261 & 1.326 & 1.389 & 1.172 \\
\hline abs coeff $\left[\mathrm{mm}^{-1}\right]$ & 0.088 & 0.247 & 0.244 & 0.078 \\
\hline crystal size $\left[\mathrm{mm}^{3}\right]$ & $0.42 \times 0.40 \times 0.22$ & $0.32 \times 0.18 \times 0.14$ & $0.43 \times 0.41 \times 0.36$ & $0.25 \times 0.19 \times 0.17$ \\
\hline $2 \theta_{\max }\left[^{\circ}\right]$ & 55.24 & 55.52 & 59.62 & 51.64 \\
\hline Index ranges & $-16 \leq \mathrm{h} \leq 16$ & $-13 \leq \mathrm{h} \leq 13$ & $-13 \leq \mathrm{h} \leq 13$ & $-15 \leq \mathrm{h} \leq 15$ \\
\hline & $-18 \leq \mathrm{k} \leq 18$ & $-18 \leq \mathrm{k} \leq 17$ & $-21 \leq \mathrm{k} \leq 19$ & $-29 \leq \mathrm{k} \leq 29$ \\
\hline & $-23 \leq 1 \leq 22$ & $-25 \leq 1 \leq 25$ & $-24 \leq 1 \leq 24$ & $-23 \leq 1 \leq 24$ \\
\hline no. of rflns collected & 114465 & 66572 & 55297 & 64136 \\
\hline no. of indep rflns & 13916 & 11731 & 14801 & 11636 \\
\hline $\mathrm{R}_{\mathrm{int}}$ & 0.0786 & 0.0701 & 0.0777 & 0.1496 \\
\hline absorption correction & none & multi-scan & multi-scan & none \\
\hline $\mathrm{T}_{\min }, \mathrm{T}_{\max }$ & - & $0.917,0.970$ & $0.902,0.917$ & - \\
\hline $\begin{array}{l}\text { data / restraints } \\
\text { /parameter }\end{array}$ & 13916 / 1 / 787 & $11731 / 5 / 688$ & $14801 / 0 / 685$ & $11636 / 9 / 721$ \\
\hline goodness of fit & 1.017 & 1.010 & 0.896 & 0.961 \\
\hline $\mathrm{R} 1, \mathrm{wR} 2[\mathrm{I}>2 \sigma(\mathrm{I})]$ & $0.0659,0.1758$ & $0.0479,0.1229$ & $0.0464,0.1104$ & $0.1027,0.2671$ \\
\hline $\mathrm{R} 1, \mathrm{wR} 2$ [all data] & $0.0822,0.1873$ & $0.0729,0.1317$ & $0.0793,0.1189$ & $0.1723,0.3205$ \\
\hline $\begin{array}{c}\text { largst diff peak and hole, } \\
\mathrm{e}^{3}\end{array}$ & $0.883,-0.650$ & $0.691,-0.542$ & $0.474,-0.514$ & $0.674,-0.751$ \\
\hline
\end{tabular}

\section{Conclusions}

Calix[4]arenes fixed in the 1,3-alternate conformation have been used for the first time as basic skeleton for the $s$ attachement of four carbamoylmethyl phosphine oxide residues or of two CMPO functions in combination with two picolinamide or (potentially ionizable) carboxylic groups. Preliminary extraction and complexation studies with selected lanthanides showed, however, that this new arrangement does not lead to improved properties in comparison to narrow or wide rim tetra-CMPO derivatives of calix[4]arenes in the cone conformation. Most probably this is not caused by the more rigid scaffold, which might be even beneficial, but to an inappropriate mutual situation of the ligating functions. MD10 simulations should be helpful to find their best arrangement.

\section{Acknowledgements}

Financial Support by the European Community (EuroPart) and by the Deutsche Forschungsgemeinschaft (SFB 625) is gratefully acknowledged.

\section{${ }_{15}$ Notes and references}

1. Horwitz, E. P.; Kalina, D. G.; Diamond, H.; V;egrift, G. F.; Schulz, W. W. Solvent Extr. Ion Exch. 1985, 3, 75-109.

2. (a) Peters, M. W.; Werner, E. J.; Scott, M. Inorg. Chem. 2002, 41, 1707-1716; V. Rudzevich, D. Schollmeyer, D. Braekers, Desreux, J. F.; Diss, R.; Wipff, G.; Böhmer, V. J. Org. Chem. 2005, 70, 6027-6033. 
3. Arnaud-Neu, F.; Böhmer, V.; Dozol, J.-F.; Grüttner, C.; Jakobi, R. A.; Kraft, D.; Mauprivez, O.; Rouquette, H.; Schwing-Weill, M.-J.; Simon, N.; Vogt, W. J. Chem. Soc., Perkin Trans. 2 1996, 1175-1182.

4. Wide rim: Delmau, L. H.; Simon, N.; Schwing-Weill, M.-J.; Arnaud-Neu, F.; Dozol, J. F.; Eymard, S.; Tournois, B.; Grüttner, C.; Musigmann, C.; Tunayar A.; Böhmer, V. Sep. Sci. Techn. 1999, 34, 863-876.

s 5. Narrow rim: Barboso, S.; Carrera, A. G.; Matthews, S. E.; Arnaud-Neu, F.; Böhmer, V.; Dozol, J.-F.; Rouquette , H.; Schwing-Weill, M.-J. J. Chem. Soc., Perkin Trans. 2 1999, 719-723.

6. Matthews, S. E.; Saadioui, M.; Böhmer, V.; Barboso, S.; Arnaud-Neu, F.; Schwing-Weill, M.-J.; Carrera, A. G. J. Prakt. Chem. 1999, 341, 264-273.

7. Arnaud-Neu, F.; Barboso, S.; Böhmer, V.; Brisach, F.; Delmau, L.; Dozol, J.-F.; Mogck, O.; Paulus, E. F.; Saadioui , M.; 10 Shivanyuk, A. Aust. J. Chem. 2003, 56, 1113-1119.

8. For early examples see: (a) Arduini, A.; Pochini, A.; Reverberi, S.; Ungaro, R. Chem. Soc., Chem. Commun. 1984, 981982; (b) Arduini, A.; Pochini, A.; Reverberi, S.; Ungaro, R.; Andreetti, G. D.; Ugozzoli, F. Tetrahedron 1986, 42, 20892100, (c) Arnaud-Neu, F.; Collins, E. M.; Deasy, M.; Ferguson, G.; Harris, S. J.; Kaitner, B.; Lough, A. J.; McKervey, M. A.; Marques, E.; Ruhl, B. L.; Schwing-Weill, M. J.; Seward, E. M. J. Am. Chem. Soc. 1989, 111, 8681-8691.

15 9. Mono-; bis -crownethers derived from the 1,3-alternate conformation are important examples, see: (a) Hill, C.; Dozol, J.-

F.; Lamare, V.; Rouquette, H.; Eymard, S.; Tournois, B.; Vicens, J.; Asfari, Z.; Bressot, C.; Ungaro, R.; Casnati, A. J. Incl. Phenom. 1994, 19, 399-408; (b) Casnati, A.; Pochini, A.; Ungaro, R.; Ugozzoli, F.; Arnaud, F.; Fanni, S.; Schwing, M. J.; Egberink, R. J. M.; De Jong, F.; Reinhoudt, D. N. J. Am. Chem. Soc. 1995, 117, 2767-2777.

10. For an example where the complexation occurs with the partial cone conformation see: van der Veen, N. J.; Egberink, 20 R. J. M.; Engbersen, J. F. J.; van Veggel, F. J. C. M.; Reinhoudt, D. N. Chem. Commun. 1999, 681-682.

11. For bis crown ethers fixed in the 1,2-alternate conformation see: Arduini, A.; Domiano, L.; Pochini, A.; Secchi, A.; Ungaro, R.; Ugozzoli, F.; Struck, O.; Verboom, W.; Reinhoudt, D. N. Tetrahedron 1997, 53, 3767-3776.

12. For a recent review see: Baklouti, L.; Harrowfield, J.; Pulpoka, B.; Vicens, J. Mini-Reviews in Organic Chemistry 2006, $3,355-384$

25 13. Arduini, A.; Böhmer, V.; Delmau, L.; Desreux, J.-F.; Dozol, J.-F.; Carrera, M. A. G.; Lambert, B.; Musigmann, C.; Pochini, A.; Shivanyuk, A.; Ugozzoli, F. Chem. Eur. J. 2000, 6, 2135-2144.

14. (a) Nigond, L.; Condamines, N.; Cordier, P. Y.; Livet, J.; Madic, C.; Cuillerdier, C.; Musikas , C.; Hudson, M. J. Sep. Sci. Technol. 1995, 30, 2075-2099; (b) Casnati, A.; Della, C.; Fontanella, M.; Sansone, F.; Ugozzoli, F.; Ungaro, R.; Liger , K.; Dozol, J.-F. Eur. J. Org. Chem. 2005, 11, 2338-2348.

30 15. Baaden, M.; Berny, F.; Madic, C.; Schurhammer , R.; Wipff, G. Solvent Extr. Ion Exch. 2003, 21, 199-220.

16. Casnati, A.; Della, C.; Fontanella, M.; Sansone, F.; Ugozzoli, F.; Ungaro, R.; Liger, K.; Dozol, J.-F. Eur. J. Org. Chem. 2005, 11, 2338-2348.

17. Kolarik, Z. Chem. Rev. 2008, 108, 4208-4252.

18. Dean, N. E.; Hancock, R. D.; Cahill, C. L.; Frisch, M. Inorg. Chem. 2008, 47, 2000-2010.

35 19. Bianchi, A.; Calabi, L.; Corana, F.; Fontana, S.; Losi, P.; Maiocchi, A.; Paleari , L.; Valtancoli, B. Coord. Chem. Rev.

2000, 204, 309-393.

20. For a recent review of actinide/lanthanide separation with multidentate lig;s see: Dam, H. H.; Reinhoudt, D. N.; Verboom, W. Chem. Soc, Rev. 2007, 36, 367-377.

21. Jakobi, R. A.; Böhmer, V.; Grüttner, C.; Kraft , D.; Vogt, W. New. J. Chem. 1996, 20, 493-501.

${ }_{40} 22$. Selective substitutions at the narrow rim can not be controlled in a similar fashion by substituents at the wide rim.

23. Danila, C.; Bolte , M.; Böhmer, V. Org. Biomol. Chem. 2005, 3, 172-184.

24. Arduini, A.; Böhmer, V.; Delmau, L.; Desreux, J.-F.; Dozol, J.-F.; Carrera M. A. G.; Lambert, B.; Musigmann, C.; Pochini, A.; Shivanyuk, A.; Ugozzoli, F. Chem. Eur. J. 2000, 6, 2135-2144.

25. For the extraction of lanthanides; actinides by calixarene-based picolinamides see ref. 16.

${ }_{45}$ 26. Herschbach, H.; Brisach, F.; Haddaoui, J.; Saadioui, M.; Leize, E.; Van Dorsselaer, A.; Arnaud-Neu, F. ; Böhmer, V.

Talanta 2007, 74, 39-46.

27. See: (a) Zhao , H.; Burke Jr., T. R. Tetrahedron 1997, 53, 4219-4230; (b) Christensen, J. B. Molecules 2001, 6, 47-51.

28. Bolte, M.; Danila , C.; Böhmer, V. Acta Crystallogr. Sect. E 2003, 59, o533-0534.

29. Lambert, T. N., Dasaradhi, L., Huber, V. J., Gopalan, A. S. J. Org. Chem., 1999, 64, 6097-6101.

so 30. Arnaud-Neu, F.; Schwing-Weill, M. J.; Ziat, K.; Cremin, S.; Harris , S. J.; McKervey, M. A. New. J. Chem. 1991, 15, 33-37.

31. Gampp, H.; Maeder, M.; Meyer , C. J.; Zuberbühler, A. D. Talanta 1985, 32, 257-264.

32. Blessing, R. H. Acta Crystallogr. Sect.. A 1995, 51, 33-38.

33. Spek, A. L. Acta Crystallogr. Sect. D 2009, 65, 148-155.

${ }_{55}$ 34. Sheldrick, G. M. Acta Crystallogr., Sect. A 2008, 64, 112-122. 


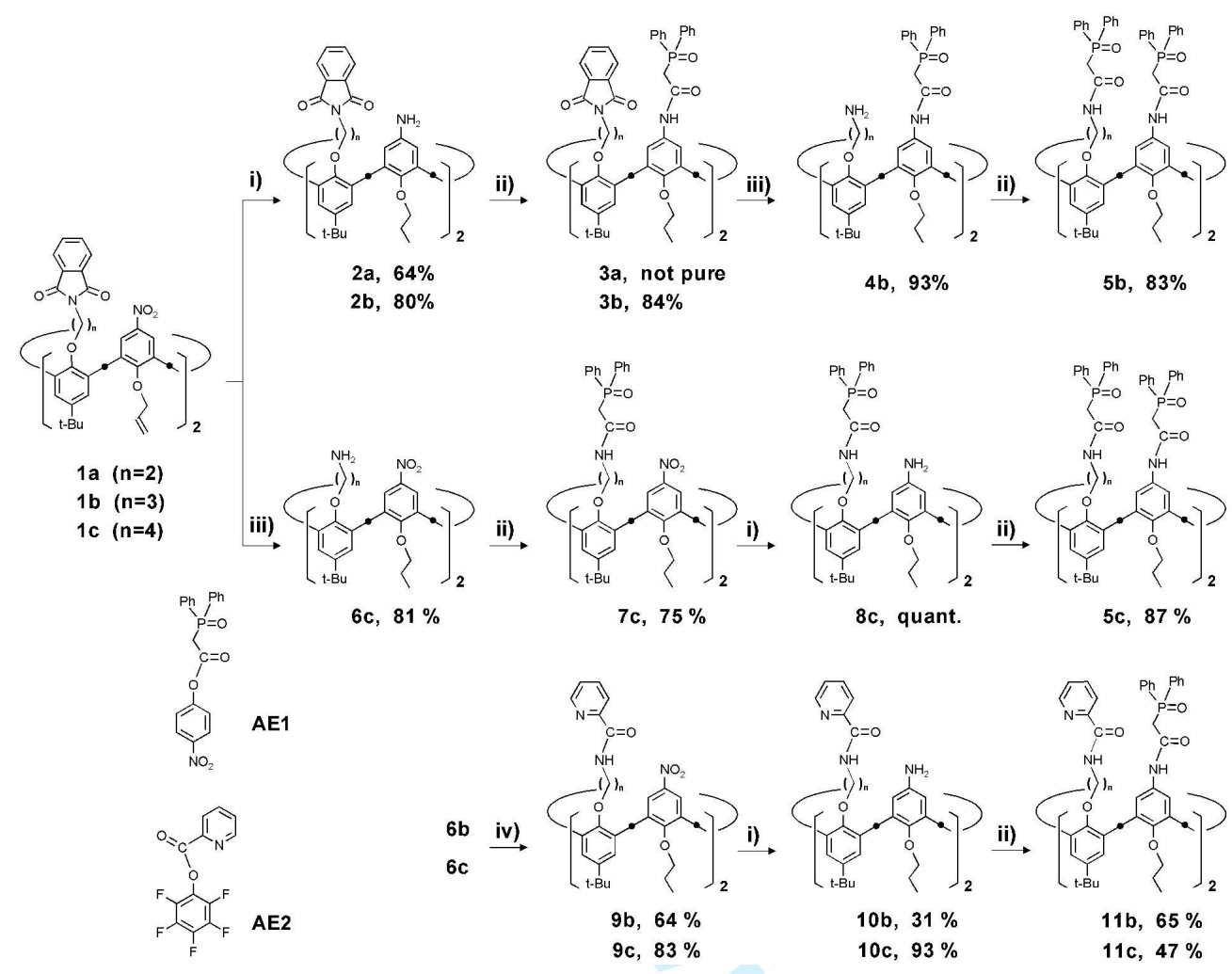




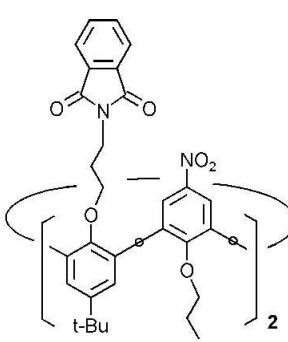

$1 b^{\prime}$

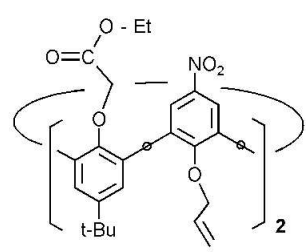

13
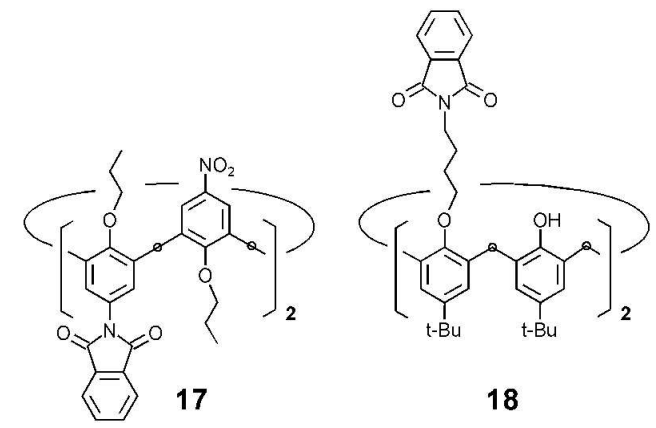

18 


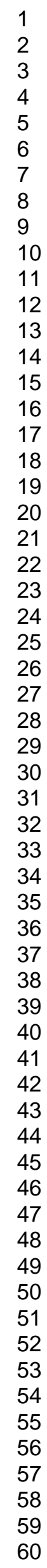

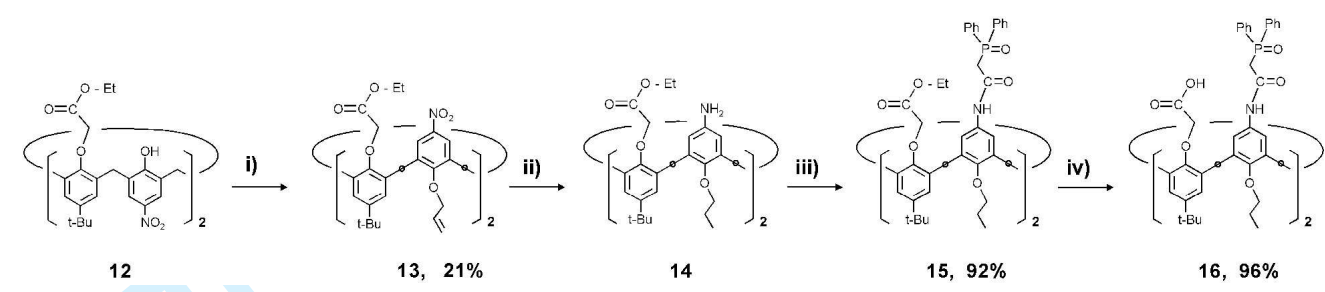

16

18

19

20

21

24

26

27

29

30

31

33

34

35

36

39

40

41

42

43

45

46

47

48

49

50

52

53

54

55

58

59

60

URL: http:/mc.manuscriptcentral.com/tandf/gsch Email: suprachem@mail.cm.utexas.edu 
1

2

3

4

5

6

7

8

10

10

11

12

13

14

15

16

17

18

19

20

21

22

23

24

25

26

27

28

29

30

31

32

33

34

35

36

37

38

39

40

41

42

43

44

45

46

47

48

49

50

51

52

53

54

55

56

57

58

59

60
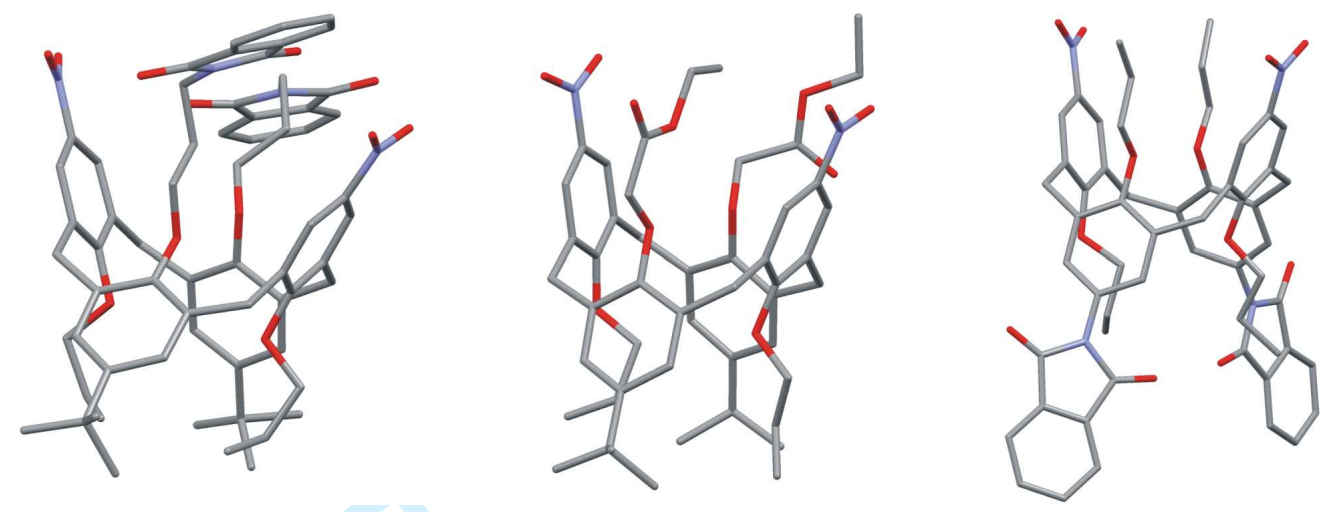

URL: http:/mc.manuscriptcentral.com/tandf/gsch Email: suprachem@mail.cm.utexas.edu 

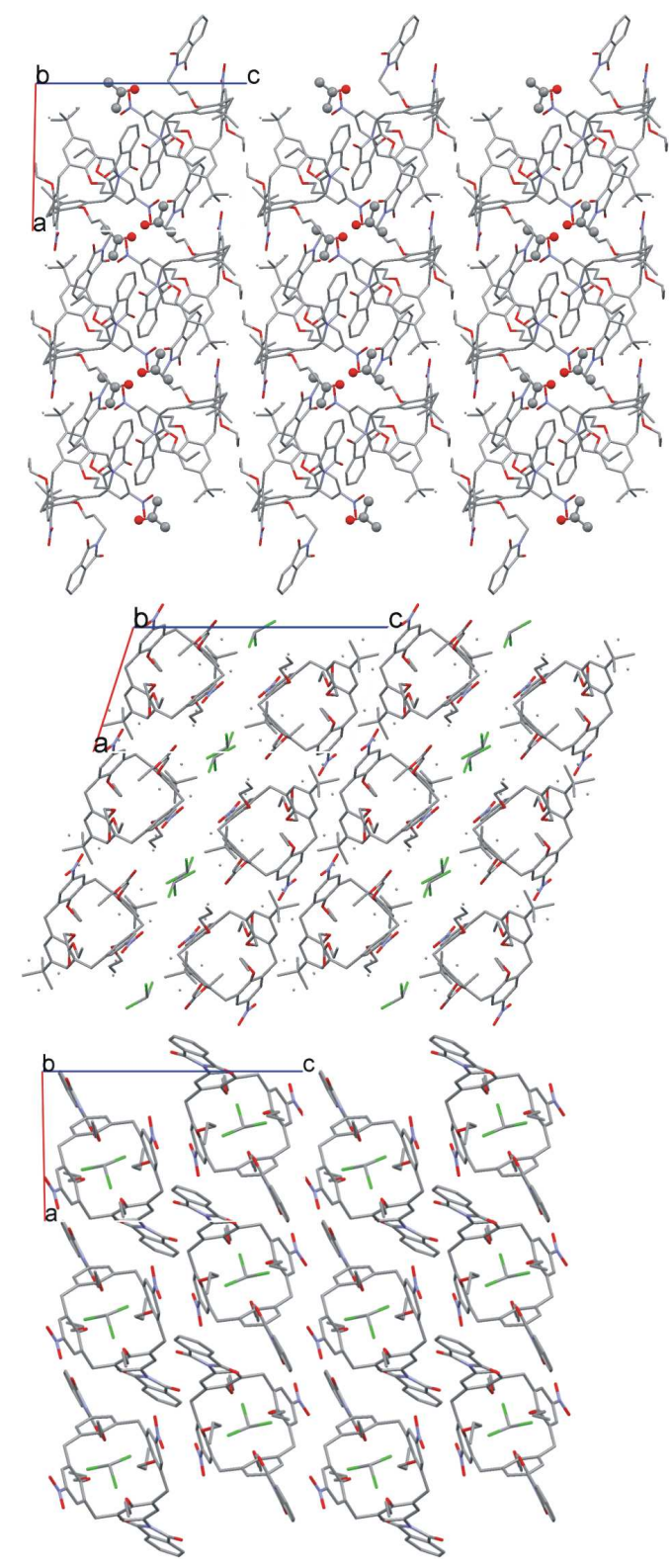

URL: http:/mc.manuscriptcentral.com/tandf/gsch Email: suprachem@mail.cm.utexas.edu 